\title{
The involvement of gonadotropin inhibitory hormone and kisspeptin in the metabolic regulation of reproduction
}

\section{F Wahab, M Shahab ${ }^{1}$ and $\mathbf{R}$ Behr}

Stem Cell Biology Unit, Leibniz Institute for Primate Research, German Primate Center, Kellnerweg 4, D-37077 Göttingen, Germany

'Laboratory of Reproductive Neuroendocrinology, Department of Animal Sciences, Faculty of Biological Sciences, Quiad-i-Azam University, Islamabad, Pakistan
Correspondence should be addressed to F Wahab

Email

fwahab@dpz.eu

\begin{abstract}
Recently, kisspeptin (KP) and gonadotropin inhibitory hormone (GnIH), two counteracting neuropeptides, have been acknowledged as significant regulators of reproductive function. KP stimulates reproduction while GnIH inhibits it. These two neuropeptides seem to be pivotal for the modulation of reproductive activity in response to internal and external cues. It is well-documented that the current metabolic status of the body is closely linked to its reproductive output. However, how reproductive function is regulated by the body's energy status is less clear. Recent studies have suggested an active participation of hypothalamic KP and $\mathrm{GnIH}$ in the modulation of reproductive function according to available metabolic cues. Expression of KISS1, the KP encoding gene, is decreased while expression of RFRP (NPVF), the gene encoding $\mathrm{GnIH}$, is increased in metabolic deficiency conditions. The lower levels of KP, as suggested by a decrease in KISS1 gene mRNA expression, during metabolic deficiency can be corrected by administration of exogenous KP, which leads to an increase in reproductive hormone levels. Likewise, administration of RF9, a GnIH receptor antagonist, can reverse the inhibitory effect of fasting on testosterone in monkeys. Together, it is likely that the integrated function of both these hypothalamic neuropeptides works as a reproductive output regulator in response to a change in metabolic status. In this review, we have summarized literature from nonprimate and primate studies that demonstrate the involvement of KP and GnIH in the metabolic regulation of reproduction.
\end{abstract}

Key Words
kisspeptin
Kiss1r
GnIH
GPR147
metabolism
reproduction
leptin
ghrelin

\section{Introduction}

Reproduction in nonprimate mammals and in primates is highly responsive to metabolic alterations (Cameron 1991, Wade \& Jones 2004). Deficiencies of metabolic fuels prevent the proper release of gonadotropin releasing hormone (GnRH) from the hypothalamus, thus causing reproductive quiescence (Bergendahl et al. 1991, Cameron et al. 1991, Wahab et al. 2013a,b). Initiation of reproductive function is delayed by conditions of negative energy balance while, in adults, merely skipping one daily meal can lead to reproductive quiescence in nonhuman primates (Kennedy \& Mitra 1963a, Foster \& Olster 1985, Cameron 1991, 1996). Food resumption regularizes the 
dysfunctional reproductive axis and normalizes reproduction (Parfitt et al. 1991). However, the exact mechanisms regarding metabolic impact on reproductive output are still poorly understood.

In the last decade, our understanding of the metabolic regulation of reproduction has been greatly enhanced through the detection of different neuroendocrine peptides. Besides many others, these include the two most recently discovered peptide hormones, kisspeptin (KP) and gonadotropin inhibitory hormone (GnIH) (Pinilla et al. 2012, Ubuka et al. 2013). KP and GnIH are two neuropeptides of the hypothalamus. They play a crucial role in the regulation of the reproductive axis. KP is a stimulator of the reproductive axis, while GnIH is the inhibitory opponent (Pinilla et al. 2012, Ubuka et al. 2013). Diverse data from a wide variety of vertebrate taxa indicate that these neuropeptides play a role in the regulation of reproduction in response to short-term (circadian) and long-term (seasonal) environmental changes (Pinilla et al. 2012, Clarke \& Parkington 2014). Moreover, both neuropeptides act as conduits/mediators for transferring the impact of body internal cues such as gonadal steroids and current energy status to the reproductive axis (Smith et al. 2007, Clarke et al. 2012, Smith 2013).

$\mathrm{GnIH}$, which is also known as RF amide-related peptide 3 (RFRP3) in mammals, is an orexigenic neuropeptide (Tachibana et al. 2005, McConn et al. 2014). However, the involvement of GnIH in the metabolic regulation of the hypothalamic-pituitary-gonadal (HPG) axis is not clearly known, but increasing data propose an involvement of this neuropeptide in negative energy balance-induced alterations in the HPG axis in mammals, including primates (Batool et al. 2014, Sabet Sarvestani et al. 2014). Recently, GnIH receptor (GnIHR) antagonist, RF9, injection has markedly reversed fasting-induced quiescent of the reproductive axis in the male adult rhesus monkey (Batool et al. 2014). In contrast, an anorexigenic effect of KP has been noted (Stengel et al. 2011). More importantly, KP has been advocated as a major signal for transferring body metabolic status-related information to the neuroendocrine reproductive axis (Castellano et al. 2010a,b, Sanchez-Garrido \& Tena-Sempere 2013, Wahab et al. 2013a).

The hypothalamic KP neurons have been reported to express receptors for leptin (Smith et al. 2006). In addition, the Kiss 1 transcript level in the hypothalamus is at its lowest level in conditions of hypoleptinemia (Smith et al. 2006, Luque et al. 2007). Moreover, leptin injection markedly heightens Kiss1 expression in the hypoleptinemic condition (Smith et al. 2006, Luque et al. 2007). A brief period of food restriction has been noted to alter Kiss1 as well as KP receptor (Kiss1r) expression (Castellano et al. 2005, Wahab et al. 2011a).

Injection of exogenous KP reverses brief food restriction-induced reproductive quiescence in rats and monkeys (Castellano et al. 2005, Wahab et al. 2008, 2014). Although KP significantly increased brief food restriction-induced attenuation of testosterone release, the response of the reproductive axis to KP administration, both in commencement and magnitude, is notably affected in adult male rhesus monkeys (Wahab et al. 2008, 2014). These observations support a possible involvement of $\mathrm{GnIH}$ and $\mathrm{KP}$ in the mediation of metabolic influence on the reproductive axis performance.

In this article, we will summarize the presently available data obtained from experimental animals, for both nonprimates and primates, implicating GnIHGnIHR and KP-Kiss1r signaling as potential vital pathways, which modify reproductive activities according to the body's existing metabolic reserves.

\section{Role of GnIH and KP in regulation of reproduction}

\section{Role of GnIH in regulation of reproduction}

About 14 years ago, GnIH was first identified in the quail brain as an inhibitor of the reproductive axis (Tsutsui et al. 2000). Later on, its mammalian orthologs were discovered to be encoded by RFRP (NPVF) gene (Hinuma et al. 2000, Yoshida et al. 2003). Now, globally, RFRP3 is regarded as the mammalian GnIH ortholog (Ubuka et al. 2013, Osugi et al. 2014). In this article, we will uniformly use GnIH for both avian and mammalian peptides.

GnIH neurons are mainly concentrated in the dorsomedial hypothalamus. The axonal fibers of these neurons form close appositions with GnRH-containing neurons in several species including nonhuman primates and humans (Kriegsfeld et al. 2006, Johnson et al. 2007, Smith et al. 2008, Ubuka et al. 2008, 2009a). This anatomical evidence suggests that GnIH can directly alter intermittent GnRH discharge from the hypothalamus. Indeed, it has been documented that direct GnIH application to GnRH neurons reduces the firing rate of a subpopulation of these neurons (Ducret et al. 2009). Besides this action on GnRH neurons, GnIH was shown to cross-talk with the HPG axis at the level of anterior pituitary gonadotropes, which express GnIHR. Moreover, GnIH may also act directly at the gonadal level (Ubuka et al. 2009b, 2014, Sari et al. 2009, McGuire \& Bentley 2010, Anjum et al. 2014).

Published by Bioscientifica Ltd 
GnIH exerts actions through its putative G-proteincoupled receptors (GPR), e.g., GPR147. GnIHR is expressed in several brain areas including GnRH-containing neurons (Fig. 1; Ubuka et al. 2008, 2009b, 2012, Rizwan et al. 2012). In addition to its hypothalamic expression, GnIHR expression has been reported in the pituitary (Ubuka et al. 2009b) and the gonads (McGuire \& Bentley 2010). The inhibitory effect of GnIH on reproductive hormones secretion can be blocked by the GnIHR antagonist RF9 (Pineda et al. 2010a,b, Rizwan et al. 2012).

Several functions, which relate to the regulation of reproduction and behavior, have been assigned to $\mathrm{GnIH}-$ GnIHR signaling on the basis of unveiling evidence over the years. This ligand-receptor duo has been described in negative feedback from gonadal steroids, as well as metabolic, circadian, and seasonal regulation of reproduction

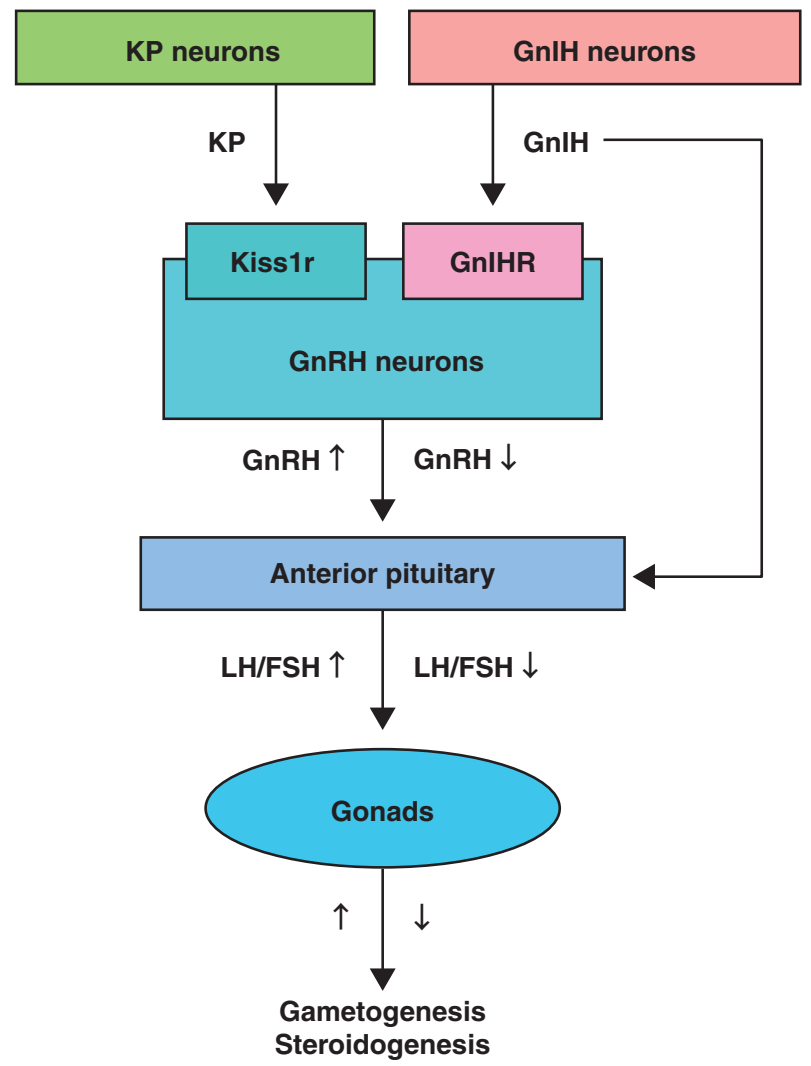

\section{Figure 1}

$\mathrm{GnIH}$ and KP signaling in the regulation of reproduction. The hypothalamic $\mathrm{KP}$ expressing neurons provide a tonic stimulatory drive to the neuroendocrine reproductive axis while GnIH neurons generate an inhibitory drive to the reproductive axis. KP acts via its $\mathrm{G}$ protein-coupled receptor, Kiss1r, while GnIH exerts actions via its G protein-coupled receptor, GnIHR. Expressions of both Kiss1r and GnIHR have been reported on the hypothalamic GnRH-containing neurons. A full colour version of this figure is available at http://dx.doi.org/10.1530/JOE-14-0688. (for a review, see Smith \& Clarke (2010), Clarke (2011), Smith (2012) and Clarke \& Parkington (2014)). While reviewing all of the data on the role of $\mathrm{GnIH}$ in the regulation of reproduction is beyond the scope of this review, here we will describe evidence suggesting its involvement in the metabolic regulation of reproduction.

\section{Role of KP in regulation of reproduction}

On the basis of a large number of molecular and physiological evidence, hypothalamic KP Kiss1r signaling has been implicated in the central control of the reproductive axis in a number of vertebrate species (Fig. 1; reviewed in Clarke (2011), Hameed et al. (2011), Wahab et al. (2011b), George \& Seminara (2012), Pinilla et al. (2012) and Terasawa et al. (2013)). The finding of the involvement of KP and its receptor Kiss1r in the initiation and maintenance of reproduction is considered as one of the most important discoveries made in the field of reproductive neuroendocrinology (Seminara \& Kaiser 2005). Since the discovery of GnRH in the late 1970s, many new peptides/neurotransmitters have been described in the neuroendocrine control of reproduction, but none has had such a dramatic effect as KP (Seminara \& Kaiser 2005, Pinilla et al. 2012).

In 2003, two groups of researchers discovered, independently from each other, that loss of function mutations of KISS1R caused hypogonadotropic hypogonadism in humans and were associated with the delay or absence of sexual maturation (De Roux et al. 2003, Seminara et al. 2003). Targeted deletions of Kiss1r/Kiss1 result in a lack of sexual behavior and a low level of gonadotropin in mice (Funes et al. 2003, Seminara et al. 2003, D' Anglemont de Tassigny et al. 2007, Lapatto et al. 2007). In addition, an activating mutation has also been described in KISS $1 R$ in humans, which leads to an early attainment of reproductive ability in pubertal females, because this mutation (Arg386Pro) results in a long-lasting activation of KISS1R in response to KP (Teles et al. 2008). Therefore, an intact KP-KISS1R system is considered to be very important in order to achieve reproductive capacity and its continuation in adults (reviewed in Seminara \& Kaiser (2005), Hameed et al. (2011), Wahab et al. (2011b), Pinilla et al. (2012) and Terasawa et al. (2013)).

Exogenous KP injection either centrally or peripherally causes stimulation of the HPG axis in many mammalian species (Thompson et al. 2004, Shahab etal. 2005, Lents et al. 2008, Pinilla etal. 2012, Okamura et al. 2013). Central as well as peripheral administration of KP10, the shortest ten amino acids peptide hormone in the KP hormone group,

Published by Bioscientifica Ltd 
or KP54, the longest one, robustly increases systemic levels of the luteinizing hormone (LH) and the follicle-stimulating hormone in sexually immature and mature rodents (Gottsch etal. 2004, Navarro etal. 2004, 2005a,b, Thompson et al. 2004). I.c.v. or peripheral KP10 administration has been shown to significantly augment GnRH-dependent LH secretion in gonadectomized sexually immature male monkeys (Shahab et al. 2005). In addition, KP10 administration increases systemic testosterone levels in adult male rats (Thompson et al. 2004) and monkeys (Wahab et al. 2008). The stimulatory effects of KP to hormones on gonadotropins are blocked by GnRH antagonists, indicating that the effect of $\mathrm{KP}$ on the reproductive axis is dependent on GnRH receptor (GNRHR) signaling and not directly through Kiss1r in the pituitary (Gottsch et al. 2004, Irwig et al. 2004, Matsui et al. 2004, Shahab et al. 2005). Moreover, KP10 administration in sheep causes an increase in the concentration of GnRH in cerebrospinal fluid (Messager et al. 2005), confirming that the action of KP on the HPG axis is mediated via modulation of GnRH release.

Therefore, the KP-induced stimulation of the HPG axis occurs via the hypothalamic GnRH neuronal network. Evidence exists for both direct and indirect KP signals to GnRH neuronal networks. The following evidence indicates that KP communicates directly with hypothalamic GnRH-secreting cells. Firstly, most GnRH-secreting cells express Kiss1r (Irwig et al. 2004, Parhar et al. 2004, Han et al. 2005, Messager et al. 2005). Secondly, KPimmunoreactive fibers are found in close apposition with GnRH-secreting cells (Clarkson \& Herbison 2006, Decourt et al. 2008, Smith et al. 2008). Thirdly, KP can act per se on in vitro GnRH-secreting cells to heighten their firing rates (Quaynor et al. 2007, Dumalska et al. 2008, Liu \& Herbison 2008, Liu et al. 2008, Pielecka-Fortuna etal. 2008). Fourthly, there has been recent evidence suggest that KP can communicate indirectly with GnRH neurons through other neurons such as glutamatergic and GABAergic neurons (Pielecka-Fortuna et al. 2008, García-Galiano et al. 2012, Di Giorgio et al. 2013).

Compelling data from various vertebrates, including mammals, suggest that KP is also involved in the mediation of gonadal steroid-negative feedback, estradiolpositive feedback during ovulation, as well as seasonal, circadian, metabolic, and stress signals to the reproductive axis (Smith 2009, 2013, Castellano et al. 2010a,b, Clarke \& Caraty 2013, Kriegsfeld 2013, Sanchez-Garrido \& TenaSempere 2013, Wahab et al. 2013a). In this article, we reviewed KP involvement in the metabolic regulation of reproduction.

\section{Evidence demonstrating the involvement of GnIH and KP in the metabolic regulation of reproduction}

\section{Presence of GnIH and KP containing cells in the brain center for feeding and reproduction control}

Besides many other functions, the hypothalamus is the brain center for the regulation of feeding and reproduction (Kennedy \& Mitra 1963b, Wynne et al. 2005). It serves as the central regulator of neuroendocrine function by controlling pituitary hormone secretion directly or indirectly. It contains a number of neuropeptides such as agouti-related peptide (AgRP), melanin-concentrating hormone, galaninlike peptide, orexin, 26RFamide, ghrelin, neuropeptide-Y (NPY), proopiomelanocortin (POMC)-derived peptides, and cocaine- and amphetamine-regulated transcript (CART), which play important roles in the regulation of feeding (Kageyama et al. 2005, Wynne et al. 2005, Crown et al. 2007, Hill et al. 2008, Wu et al. 2009, Galusca et al. 2012). Some of these are orexigenic neuropeptides while others are anorexiegenic neuropeptides.

KISS1 and GnIH mRNA expressing neurons have also been consistently reported in hypothalamic tissues of diverse taxa including primates (Irwig et al. 2004, Castellano et al. 2005, Shahab et al. 2005, Smith et al. 2008, Ubuka et al. 2009a,b, Escobar et al. 2013, Sabet Sarvestani et al. 2014, Ohga et al. 2015). As discussed previously, the peptide products of these two genes have been implicated as the main central regulator of the reproductive axis (reviewed in Smith \& Clarke (2010), Tsutsui et al. (2010), Clarke (2011), Pinilla et al. (2012), Tena-Sempere et al. (2012) and Ogawa \& Parhar (2014)). Moreover, these neuropeptides also modulate food intake. GnIH has been noted to stimulate feeding (Clarke et al. 2012, McConn et al. 2014) while KP has an anorexigenic effect in fasted mice (Stengel et al. 2011). Significantly, early studies in rats did not observe any change in food intake after KP injection under both food restriction and ad libitum feeding conditions (Thompson et al. 2004, Castellano et al. 2005). This difference in findings may be due to species differences or variations in experimental set up. Automated noninterfering food intake monitoring was performed in studies with mice, while in studies with rats a manual assessment was done (Thompson et al. 2004, Castellano et al. 2005, Stengel et al. 2011).

These neurons, containing KP and GnIH, are also expressing receptors of the metabolic hormones (Smith et al. 2006, Poling et al. 2014, Ratra \& Elias 2014). Importantly, the activities of these neurons, as will be

Published by Bioscientifica Lto 
discussed below, are altered during negative energy balance conditions (Castellano \& Tena-Sempere 2013, Wahab et al. 2013a, Roa \& Tena-Sempere 2014). Also, these neurons have been documented to directly cross-talk with GnRH-containing neurons (Irwig et al. 2004, Parhar et al. 2004, Han et al. 2005, Messager et al. 2005, Clarkson \& Herbison 2006, Decourt et al. 2008, Smith et al. 2008, Ubuka et al. 2008, 2009b, 2012, Rizwan et al. 2012). Moreover, expression of KP and GnIHRs has been noted on GnRH neurons (Irwig et al. 2004, Parhar et al. 2004, Han et al. 2005, Messager et al. 2005, Ubuka et al. 2009b). Therefore, this multifaceted neural circuit of hypothalamic neurons can act to integrate alterations in metabolic homeostasis with the neuroendocrine regulation of the HPG axis function.

GnIH and KP can also indirectly convey the body's current energy reserve-related information to the neuroendocrine center controlling reproductive axis. Several studies have demonstrated GnIH and KP receptor expression (Shahab et al. 2005, Clarkson \& Herbison 2006, Kriegsfeld et al. 2006, Decourt et al. 2008, Ubuka et al. 2008) in many different areas of the hypothalamus. Backholer et al. (2010) reported the existence of reciprocal input between the hypothalamic KP-containing neurons and anorexigenic POMC neurons and orexigenic NPY neurons in the ovine hypothalamus, while Qi et al. (2009) documented that GnIH neurons project to NPY, POMC, and orexin-containing neurons in sheep brains. These anatomical connections propose an essential role of $\mathrm{GnIH}$ and KP cells in integrating current metabolic status to the HPG axis output. Indeed, GnIH and KP administrations altered expression of both POMC and NPY mRNA (Fu \& van den Pol 2010, Kim et al. 2010, Jacobi et al. 2013). In addition, KP directly stimulates POMC cells, while it indirectly suppresses hypothalamic NPY cells (Fu \& van den Pol 2010). Jacobi et al. (2013) reported a negative effect of GnIH on POMC cells (Jacobi et al. 2013). They also noted a negative effect of GnIH on the activity of NPY cells in mice. Of note, it has been shown that activation of the NPY-Y1 receptor is required for the physiological amplification of the spontaneous preovulatory LH surge in rats (Leupen et al. 1997). Therefore, GnIH inhibition of NPY cells can also contribute to the inhibitory effect of GnIH on LH surge.

The above mentioned data indicate both a direct and indirect involvement of GnIH and KP in linking metabolic status-related information with the feeding or reproductive axis (Fig. 2). Reciprocal input from orexigenic and anorexigenic neuronal systems to GnIH and KPcontaining neurons is also possible, which may affect

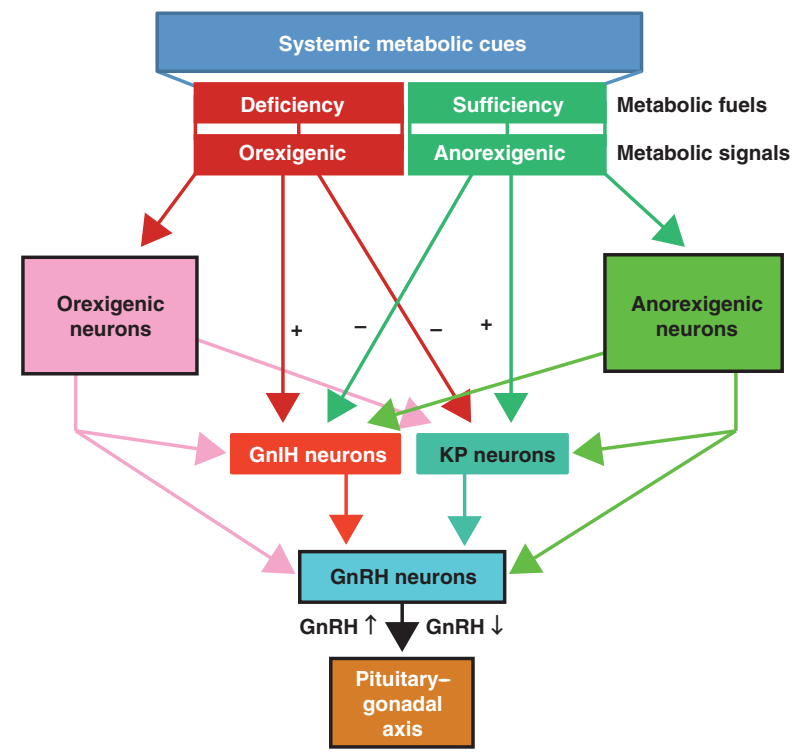

Figure 2

Schematic representation of the interaction of metabolic cues with GnIH and KP signaling. Metabolic fuel deficiency and sufficiency differentially modulate the activities of KP and GnIH containing neurons. The deficiency of metabolic cues, either directly or indirectly via orexigenic factors, decreases KP neuronal activities and increases GnIH neuronal activities. In contrast, metabolic cue sufficiency, either per se or through anorexigenic signals, decreases $\mathrm{GnIH}$ neuron activities and increases the activities of KP neurons. GnIH and KP neurons can receive current metabolic status-related information from orexigenic and anorexigenic neurons as well. Likewise, orexigenic and anorexigenic neurons can also directly convey current metabolic status-related information to $\mathrm{GnRH}$ neurons. A full colour version of this figure is available at http://dx.doi.org/10.1530/JOE-14-0688.

RFRP and KISS1 expression as well as the release of their peptide products. In support of this notion, Luque et al. (2007) noted a defective expression of Kiss1 in Npyknockout mice and suggested that a normal NPY neuronal network is essential for KP-containing neurons to function accurately. Similarly, dynorpin A and neurokinin B coexpressions have been identified on KPergic neurons (Goodman et al. 2013). It will be interesting to know whether KP and GnIH neurons contain receptors for $A g R P$, $N P Y, G A L P, C A R T$, and POMC or receive afferent projections from these neuronal networks of the feeding and satiety center. Of note, reciprocal connections from POMC and $N P Y$ to KP neurons in the ovine brain have already been shown by Backholer et al. (2010). The functional significance of this connection is supported by a positive effect of melanocortin agonist on KP neurons in the preoptic area of ewes (Backholer el al. 2009). In the same vein, a potent stimulatory effect of CART, another anorexigenic neuropeptide of the hypothalamus, has also been noted on KP neurons (True et al. 2013). Recently, electrophysiological studies have demonstrated the

Published by Bioscientifica Ltd 
importance of KP for the stimulatory effect of NPY antagonism on the GnRH (Verma et al. 2014). Although there are no in vivo data on the effect of NPY on KP neuronal activities, an in vitro study reported a stimulatory effect of NPY on Kiss 1 expression in hypothalamic cell line N6 (Luque et al. 2007).

\section{KP and GnIH signaling during puberty}

Puberty is an important stage in mammalian reproduction. It is characterized by prominent changes in the activity of the reproductive axis (Terasawa \& Fernandez 2001). The starting mechanisms of puberty have begun to be properly deciphered in light of recent advances in neuroendocrinology of reproduction. Puberty is regulated by both genetic and nongenetic factors. The important role of metabolic cues in puberty regulation is well established. Many studies have reported that an altered energy balance at the time of puberty severely affects the normal activation of the reproductive axis (Wade \& Jones 2004, Castellano et al. 2010a).

During the prepubertal period, the body's metabolic reserves exert a vital influence on the pubertal awakening of the HPG axis (Kennedy \& Mitra 1963a, Foster \& Olster 1985). Metabolic stress and energy imbalance conditions in humans, such as anorexia, morbid obesity, are characterized by perturbation in the achievement of reproductive capacity at the time of puberty (Castellano et al. 2010a, Sanchez-Garrido \& Tena-Sempere 2013). A large number of studies have demonstrated that metabolic insufficiency during this critical period of reproductive ability realization delays or prevents the awakening of the HPG axis in rats (Kennedy \& Mitra 1963a, Schenck et al. 1980), mice (Marsteller \& Lynch 1983, Perrigo \& Bronson 1983), lambs (Foster \& Olster 1985), Syrian hamsters (Morin 1975), and humans (Teles et al. 2008).

Metabolic imbalance has an impact on the reproductive axis via alteration in KP signaling (Wahab el al. $2013 a, b)$. In nonprimate studies, food restriction delayed the achievement of puberty hallmarks, compared with the control condition, while KP injections caused early achievement of puberty (Castellano et al. 2005). These data indicate that metabolic insufficiency attenuated KP release during this critical period. Indeed, Kiss1 expression is reduced under food restriction conditions (Castellano et al. 2005, Wahab et al. 2011a, Sabet Sarvestani et al. 2014). In mammalian studies, a permissive role of the metabolic hormone leptin has been suggested in puberty and reproduction (Grumbach 2002, Terasawa et al. 2012, Sanchez-Garrido \& Tena-Sempere 2013). However, it is unclear whether leptin acts at the hypothalamic, pituitary, or gonadal level to permit activation of the reproductive axis. Available data indicate all these possibilities. LepR is expressed on many different hypothalamic neuronal populations, including KP neurons that directly or indirectly modulate GnRH neuronal activity (Quennell et al. 2009, Donato et al. 2011, Zuure et al. 2013, Bellefontaine et al. 2014, Martin et al. 2014). The action of leptin on pituitary gonadotropes is suggested by the fact that these cells express the LepR, and leptin modulates the LH surge (Crane et al. 2007, Akhter et al. 2014). A more recent study has shown that loss of LepR in gonadotropes results in reduced GNRHR expression and LH secretion (Akhter et al. 2014).

However, there are no data on the impact of changes in metabolic cues on the GnIH neuronal activity during prepuberty or at the onset of puberty. Therefore, it will be worthwhile for future studies to focus on the interaction between metabolic cues and GnIH in prepubertal and pubertal stages.

\section{KP and GnIH signaling in metabolic insufficiency conditions of fasting}

The performance of the reproductive axis during various time periods of food restriction has been extensively studied in mammals (Marsteller \& Lynch 1983, Cameron 1996, Shahab etal. 1997, Wahab etal. 2008, 2014). Both short- and long-term food restrictions have been observed to cause quiescence of the HPG axis. In macaques, it has been noted that merely missing a single daily meal or a change in its timing can cause reproductive quiescence (Cameron 1996). Besides modulation of pituitary GNRHR expression (Crane et al. 2007), food restriction also induces reproductive quiescence by a decrease in GnRH release from the hypothalamus (Bergendahl et al. 1991, Aloi et al. 1997, Wahab et al. 2008). Nevertheless, the mechanism by which food restriction disturbs neural circuits that govern the pulsatile GnRH release is not fully understood at present.

Recently, we have carried out an analysis of the KP effect on the reproductive quiescence in various time periods of fasting in adult male rhesus macaques. I.v. injections of KP10, a decapeptide of the KP hormone family, caused a prominent augmentation of plasma testosterone levels in 12, 18, 24, and $48 \mathrm{~h}$ food-restricted monkeys (Wahab et al. 2008, 2014). In terms of initiation and magnitude, KP injection-induced testosterone response in the 12-h fasted macaque monkey was similar to that of normally fed monkeys. However, the KP10 injection-induced testosterone response was lowered both

Published by Bioscientifica Ltd 
in initiation and magnitude in 18,24 , and 48 -h food-deprived monkeys (Wahab et al. 2008, 2014). Therefore, these observations suggest that injection of exogenous KP incompletely reverses more than 12 -h food restriction-induced reproductive quiescence. These results suggest that brief fasting conditions may cause a drop in KPergic neuron output to the neuronal network regulating the pulsatile release of $\mathrm{GnRH}$, which in turn causes a decline in LH and testosterone systemic levels. Recently, we have reported in another study a reduction in Kiss1 mRNA in the hypothalami of food-deprived macaques (Wahab et al. 2011a).

A number of studies in other models have also demonstrated a marked attenuation in Kiss1 transcript levels in the hypothalamus under food restriction conditions along with inhibition of the reproductive axis. Injections of exogenous KP reverse the reproductive quiescence in these animals (Castellano et al. 2005, Luque et al. 2007). On the basis of available data, it is well established that the hypothalamus is the major site of KP action on the reproductive axis (Batool et al. 2014). Therefore, in a fasting situation, KP-induced stimulation of the reproductive axis also occurs via its action on the hypothalamic GnRH release. Nevertheless, whether KP acts directly or indirectly is still not clear. Based on observations, a direct action is suggested by the evidence that GnRH neurons express Kiss1r (Irwig et al. 2004, Parhar et al. 2004, Han et al. 2005, Messager et al. 2005), while in an indirect action KP modulates the activity of other hypothalamic neuronal networks which crosstalk with GnRH neurons (Fu \& van den Pol 2010, Kim et al. 2010).

Recently, we have reported that GnIHR antagonism via injections of RF-9 in food-deprived macaques reinstated lowered levels of testosterone to the normal levels of fed animals (Batool et al. 2014). From this, one can infer that GnIH is one of the main inhibitory drivers to the reproductive axis in negative energy balance conditions, while the blocking of GnIH action permits reproduction. However, it is still unclear where GnIH crosstalk takes place with the reproductive axis. Whether GnIH prevents testosterone release in fasted animals indirectly via constraining GnRH pulsatile release and/or preventing LH secretion from pituitary gonadotrophs, or directly by acting per se on testes to stop testosterone release, warrants further scholarly investigation.

The nature of the fasting metabolic insufficiencyinduced signals that alter GnIH and KP signaling is not known. However, a possible mechanism through which fasting may alter GnIH and KP signaling is illustrated in Fig. 2. Important candidates in this respect are peripheral metabolic cues and their receptive hypothalamic neuronal circuits. Important metabolic cues are adiponectin, glucose, ghrelin, cortisol, insulin, leptin, or other metabolic molecules (Kinoshita et al. 2003, Budak et al. 2006, Wahab et al. 2010, 2011c, 2013a, Poling et al. 2014, Roa \& Tena-Sempere 2014). Glucose is a ubiquitous cue for all organisms. It is the primary fuel for neurons. Therefore, it can mediate metabolic insufficiency-related information to GnIH and KP neurons. But this notion is ruled out by findings that in acute insulin-induced hypoglycemia, the sensitivity of GnRH cells to KP treatment remains preserved (Wahab et al. 2012).

Leptin, ghrelin, and cortisol are other important candidates. All of these are implicated in altering the expression of hypothalamic Kiss1 (Smith et al. 2006, Luque et al. 2007, Forbes et al. 2009, Kinsey-Jones et al. 2009). Important roles of the adipokine hormone leptin in the metabolism and reproduction have recently been extensively reviewed (e.g., Moschos et al. 2002, Budak et al. 2006, Sanchez-Garrido \& Tena-Sempere 2013, Tena-Sempere 2013, Nestor et al. 2014, Roa \& Tena-Sempere 2014). The proper functioning of various hypothalamic neuronal populations is sensitive to systemic leptin levels (Casanueva \& Dieguez 1999, Pralong \& Gaillard 2001, Moschos et al. 2002). Recently, KP neurons have been noted to express LepR, the receptor of leptin. In mice, about $40 \%$ of KPergic neurons in the arcuate nucleus express LepRs (Smith et al. 2006). In sheep, expression of LepR has also been documented on KP-containing neurons in the medial preoptic area (Backholer et al. 2010). In situations of altered energy balance including food restriction, low systemic concentration of leptin leads to a low hypothalamic level of Kiss 1 mRNA (Castellano et al. 2005, Smith et al. 2006, Luque et al. 2007, Wahab et al. 2011a), while administration of leptin greatly ameliorates transcript levels of Kiss1 (Smith et al. 2006, Luque et al. 2007, Backholer et al. 2010). In lean sheep, a model of energy deficiency characterized by low stores of energy reserves, hypogonadotropic hypogonadism and low leptin levels, reduced Kiss1 mRNA expression has been observed in both the arcuate nucleus (ARC) and preoptic area (Backholer et al. 2010). Consequently, leptin infusion increases Kiss1 mRNA expression in both the ARC and preoptic area in these animals. This finding suggests a role of both the ARC and preoptic area in relaying metabolic information to the reproductive axis. Altogether, these observations propose that leptin is one of direct metabolic signals that modulate the functioning of KP-containing neurons in the hypothalamus during situations of negative energy balance and hence, ultimately, reproductive output. Nevertheless, recent

Published by Bioscientifica Ltd 
studies have demonstrated that leptin transfers information about metabolic status to KP-containing neurons indirectly because leptin administration fails to phosphorylate the STAT3, a key component of a major intracellular signaling pathway mediating leptin action, in KP neurons (Louis et al. 2011). Indeed, leptin receptors are located on many neuronal populations in the hypothalamus (Wada et al. 2014) which cross-talk with KPergic neurons (Backholer et al. 2010, Fu \& van den Pol 2010, Kim et al. 2010).

Ghrelin, a gut metabolic hormone, stimulates food intake (Pusztai et al. 2008). Recently, it has been shown to reduce Kiss 1 transcript levels in the hypothalamus. Exogenous injections as well as food restriction induced hyperghrelinemia have been documented to decrease mRNA levels of Kiss1 (Forbes et al. 2009, Frazao et al. 2014). These findings indicate that ghrelin-induced reduction in hypothalamic Kiss1 expression can be one of the key factors in metabolic deficiency-induced inhibition of the reproductive axis. At this time, the effect of ghrelin on the activity of GnIH-containing neurons is not known.

Although recently it has been noted that GnIH neurons are not responsive to leptin, glucocorticoid receptor expression has been observed on GnIHcontaining neurons which are upregulated by both acute and chronic stress (Gojska \& Belsham 2014, Poling et al. 2014, Rizwan et al. 2014). As fasting is a type of metabolic stress and an increase in glucocorticoid has been reported in this condition (Wahab et al. 2008), it is possible that glucocorticoid may alter the GnIH system, which may communicate inhibitory information to the reproductive axis (Smith \& Grove 2002). Moreover, the KP neuronal system is also negatively affected by stress signals (Kinsey-Jones et al. 2009). Whether GnIH and KP neuronal systems are also modulated by changes in glucocorticoids during metabolic stress warrants further investigation. More importantly, it would be worthwhile to study the level of impact of stress vs metabolic signals on KP and GnIH systems during metabolic insufficiency conditions.

\section{KP and GnIH signaling in conditions of altered energy balance and reproduction}

In contrast to metabolic insufficiency situations of fasting, there are some conditions of altered energy balances such as diabetes and obesity, etc. in which more than enough stores of metabolic energy are present, but the body cannot use them (Sexton \& Jarow 1997, Cleary et al. 2001, Smith et al. 2010a). Therefore, in these conditions, the malfunction of the reproductive axis has also been attributed to an altered energy balance. In this part, we summarize the data that proposes the role of GnIH and KP in modifying the HPG axis in various conditions of energy imbalance (Table 1).

Lactation During lactation, the negative energy balance and suckling stimulus have been implicated in the suppression of the reproductive axis (Russell et al. 2001, Smith \& Grove 2002). The negative energy balance results from a huge energy drain due to the production of milk. The lactation-induced reproductive quiescence is caused by impairments at both upstream and downstream of GnRH (Smith 1978, Lee et al. 1989). Reduced levels of GNRHR in the pituitary and impaired pituitary responsiveness to GnRH have been suggested as possible downstream mechanisms (Smith 1978), while alterations in hypothalamic pathways involving KP and GnIH have been suggested as an upstream mechanism.

Hypothalamic GnIH-GnIHR signaling and KP-Kiss1r signaling are potential pathways that can relay negative energy balance and suckling stimulus-related information to the GnRH neuronal network as shown in Fig. 3 (Smith et al. 2010a, Liu et al. 2014). An obvious increase in GnIH was reported in the hypothalamus of lactating

Table 1 Summary of Rfrp and Kiss1 mRNA expression in various paradigms of altered metabolic homeostasis

\begin{tabular}{lccc}
\hline Metabolic paradigm & & Kiss1 mRNA & RFRP mRNA \\
\cline { 1 - 2 } Fasting & - & - & + \\
Lactation & - & & + \\
STZ-induced diabetes & - & $=$ \\
Diet-induced obesity & - & \\
Ob/Ob mice & &
\end{tabular}

Reference
Castellano et al. (2005), Wahab et al. (2011a) and
Jahanara et al. (2014)
Yousefabad et al. (2013) and Liu et al. (2014)
Castellano et al. (2006)
Quennell et al. (2011), Luque et al. (2007) and
Rizwan et al. (2014)
Smith et al. (2006), Quennell et al. (2011) and
Rizwan et al. (2014)

+ , increase; - , decrease; =, no effect; ?, currently unknown http://joe.endocrinology-journals.org DOI: $10.1530 / J O E-14-0688$
(C) 2015 The authors Printed in Great Britain
Published by Bioscientifica Ltd 


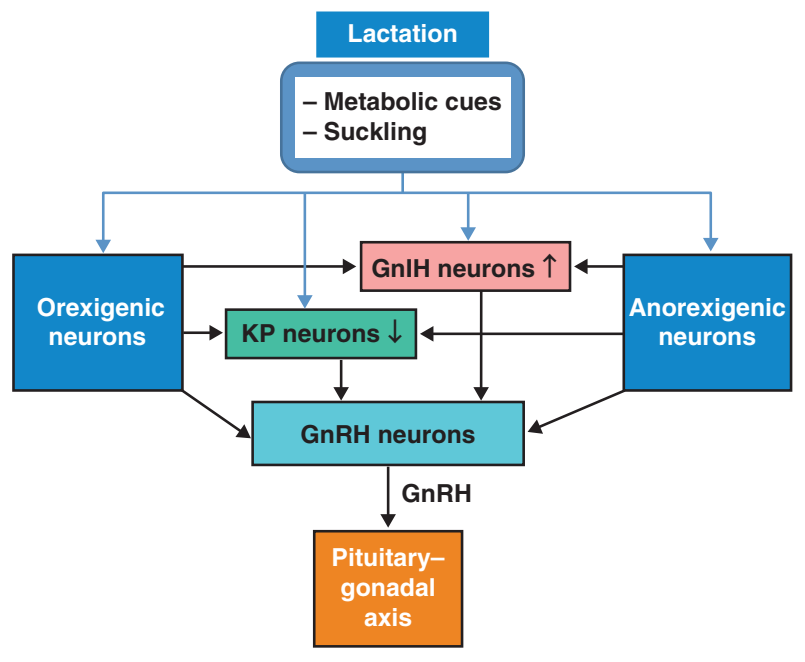

Figure 3

A possible mechanism of lactation-induced suppression of the reproductive axis. Metabolic cues and suckling stimulus during lactation can alter the activities of KP and GnIH-containing cells both directly and indirectly. In the former case, lactation-specific metabolic changes increase the activities of GnIH neurons and attenuate KP neuronal activities. These neurons then act accordingly on the GnRH neurons. In the latter case, KP and GnIH neurons receive information from orexigenic and anorexigenic neurons and, in turn, convey the impact of this information to the reproductive axis via $\mathrm{GnRH}$ neurons. Likewise, orexigenic and anorexigenic neurons can also convey lactation-specific information to GnRH neurons. A full colour version of this figure is available at http://dx.doi.org/10.1530/JOE-14-0688.

gonadectomized rats, while Kiss1 transcript levels were markedly attenuated (Yamada et al. 2007, Yousefabad et al. 2013, Liu et al. 2014). Moreover, these gonadectomized rats maintain normal responsiveness to injection of KP. KP administration-induced LH response was comparable between lactating and nonlactating female rats (Yamada et al. 2007). Although Roa et al. (2006) noted that the magnitude of KP-induced LH secretory responses was greatly reduced in lactating female rats as compared with pair-control animals. Thus, a noteworthy influence of lactation on the GnRH neuronal sensitivity to KP in terms of gonadotropin secretion was reported. Altogether, these results suggest that an increase in expression of the $R$ frp gene during lactation may cause higher synthesis and release of GnIH. In addition, a decrease in the Kiss1 gene expression may lead to lower KP synthesis and release. These alterations in GnIH and KP could reduce the intermittent discharge of GnRH and thus ultimately lead to inhibition of the HPG axis during lactation. Presently, the nature of the factors responsible for the stimulation of $R$ frp and attenuation of Kiss 1 expression during lactation is unclear, but it is logical to predict them as a combination of different peripheral and central signals that cause a rise in lactation-associated food ingestion. It has been reported that circulating leptin levels are lowered in lactating rats compared with nonlactating animals (Denis et al. 2003). Moreover, lactation is associated with reduced expression of anorexigenic POMC and increased expression of orexigenic AGRP and NPY (Suzuki et al. 2014). Since leptin, POMC, AGRP, and NPY affect the $\mathrm{KP} / \mathrm{GnIH}-\mathrm{GnRH}$ system, they can also modulate Rfrp and Kiss1 expression during lactation. Of note, a very recent study demonstrated an important role of prolactin in the lactation-induced suppression of KP release and reproduction (Brown et al. 2014).

Obesity A good model for studying the pathophysiology of obesity is the $\mathrm{Ob} / \mathrm{Ob}$ mice, which is deficient in the leptin encoding gene (Mounzih et al. 1997, Cleary et al. 2001). These mice develop severe obesity along with a malfunctioning reproductive system. The main cause of hypogonadism in these mice is considered to be of central hypothalamic origin because the gonadal response to LH and pituitary sensitivity to GnRH remain preserved (Mounzih et al. 1997, Cleary et al. 2001). Of note, it was noted that these mice have disrupted expression of Kiss1 mRNA in the hypothalamus (Smith et al. 2006). Exogenous applications of leptin have been noted to augment Kiss 1 gene expression in this model of obesity (Smith et al. 2006). As a number of studies have reported that leptin infusions also rescue reproductive quiescence in $\mathrm{Ob} / \mathrm{Ob}$ mice (Mounzih et al. 1997, Cleary et al. 2001), we cautiously propose that the impaired KPKiss1r signaling contributes at least partly to reproductive impairments caused by leptin deficiency.

More recently, analyses of the function of leptin on the GnIH-GnIHR system have been carried out in these mice (Poling et al. 2014, Rizwan et al. 2014). Only a small subset of GnIH neurons expresses the LepR (Poling et al. 2014). These results suggest a lack of an essential role of the GnIH in linking leptin with reproductive function under these conditions. Rizwan et al. (2014) did not observe any differences in hypothalamic Rfrp gene mRNA levels or GnIH-immunoreactive cell number in $\mathrm{Ob} / \mathrm{Ob}$ and control animals, or in high-fat and low-fat diet-fed control mice. In addition, they did not detect expression of $L e p R$ in GnIH cells. Moreover, they did not see leptin-induced STAT3 in vicinity to GnIH-containing neurons, but there was a small amount (2-13\%) of co-localization and no noteworthy differences between control and leptininjected mice (Rizwan et al. 2014).

Diabetes Diabetes, a metabolic disorder, is characterized by either dysfunction of pancreatic $\beta$-cells or resistance to insulin, an important metabolic hormone. Hyperglycemia

Published by Bioscientifica Ltd 
is a hallmark of diabetes (Spindler-Vomachka \& Johnson 1985, Sexton \& Jarow 1997, Clough et al. 1998). Diabetic patients as well as animal models of diabetes are characterized by secondary hypogonadism. A number of studies have reported preserved GnRH content as well as its secretory capacity in the hypothalamus, suggesting that the central cause of reproductive impairment in diabetic human patients and experimental diabetic animals lies upstream of GnRH neurons (Howland \& Zebrowski 1976, 1980, Spindler-Vomachka \& Johnson 1985, Sexton \& Jarow 1997, Clough et al. 1998). This notion is supported by recent studies in human diabetic patients and diabetic rats, which demonstrated that pituitary response in terms of LH discharge to exogenous $\mathrm{KP}$ injections remains conserved (Castellano et al. 2006, George et al. 2013). Therefore, the primary defect responsible for quiescence of the reproductive axis more likely involves a reduction in KP stimulatory drive to the hypothalamic GnRH cells. Of note, hypothalamic Kiss 1 expression is greatly decreased in diabetic rats (Castellano et al. 2006).

In the diabetic model, hypoleptinemia has been suggested to more likely be a causative agent responsible for reduced Kiss1 expression because infusion of exogenous leptin markedly enhanced hypothalamic levels of Kiss 1 mRNA, while insulin-like growth factor and insulin failed to do so (Luque et al. 2007). Although Luque et al. (2007) did not observe an effect of insulin on Kiss 1 expression, the presence of an insulin receptor (IR) on KP neurons in the $\mathrm{ARC}$ of the hypothalamus gives a clue as to the importance of insulin-KP signaling. Indeed, a recent study by Qiu et al. (2013) has demonstrated that specific ablation of the IR from KP neurons results in delayed puberty although no impact on the reproductive capacity of adult animals is noted.

Pregnancy Pregnancy is a physiological condition that is characterized by a rise in the body's basal metabolic rate along with a decrease in hypothalamic GnRH and pituitary LH discharge (Linkie \& Niswender 1972, Morishige et al. 1973, Boyle \& Roth 2012). Recently, Sabet Sarvestani et al. (2014) have reported that attenuation of GnRH and LH discharge during pregnancy in rats may be regulated by a persistent Rfrp mRNA expression and diminished Kiss1 mRNA expression.

\section{Expression and action of GnIH-GnIHR and KP-Kiss1r signaling in peripheral tissues implicated in energy homeostasis and reproduction}

Careful analyses of the expression of components of GnIH-GnIHR and KP-Kiss1r signaling pathways show that these are highly active in two kinds of organs: i) those that are involved in the maintenance of metabolic homeostasis and ii) those that control reproduction. The pituitary, which is vital in the control of metabolic homeostasis and reproduction, highly expresses Rfrp, GnIHR, Kiss1, and Kiss1r (Lee et al. 1996, Muir et al. 2001, Ohtaki et al. 2001, Shahab et al. 2005, Ubuka et al. 2009b, Bentley et al. 2010, Smith et al. 2010a,b, Tsutsui et al. 2010, Wahab et al. 2011a, Cejudo Roman et al. 2012, Irfan et al. 2014, Osugi et al. 2014).

Furthermore, expression of some of these genes has been reported in the adipose tissue, adrenal gland, placenta, pancreas, and intestine (Lee et al. 1996, 1999, Ohtaki et al. 2001, Brown et al. 2008). These organs are crucial for the maintenance of metabolic homeostasis. Likewise, these genes are also expressed in the primary sex organs, ovaries, and testes, which drive reproduction (Ohtaki et al. 2001, Bentley et al. 2010, Li et al. 2012, Irfan et al. 2014). While the roles of GnIH-GnIHR and KP-Kiss1r in the functioning of these peripheral organs are not fully understood at present, the modulation of these organs' endocrine secretion by the administration of GnIH and KP suggests a significance of GnIH and KP expression in the periphery.

\section{Infection/immune challenge induced malnutrition-related alterations in hypothalamic KP signaling}

It is well known that infection/immune challenges cause an inhibition of the reproductive axis (Fig. 4) (Wahab et al. 2013b). It is also known that infection/immune challenges result in a kind of metabolic deficiency state by various mechanisms. These include an increase in energy expenditure concurrently with a decrease in food intake, an increase in secretion of catabolic hormones such as corticosteroids and catecholamines, stimulation of the anorexigenic $(\alpha$-melanocyte-stimulating hormone and corticotropinreleasing hormone), and inhibition of orexigenic (agoutirelated protein) hypothalamic neuropeptides by cytokines, as well as an increase in cytokine-induced thermogenesis (Beisel 1995, Wahab et al. 2013b). However, the mechanistic link between infection/immune challenges and reproduction is still poorly understood.

Lipopolysaccharide (LPS) administration has been shown to greatly decrease the hypothalamic levels of Kiss1 mRNA and reduce systemic levels of LH in gonadectomized rats (Iwasa et al. 2008, 2014, Castellano et al. 2010b). The inhibitory effect of LPS on the expression of hypothalamic mRNA levels of Kiss1 and systemic levels of LH is fully reversed by indomethacin, a nonsteroidal

Published by Bioscientifica Ltd 


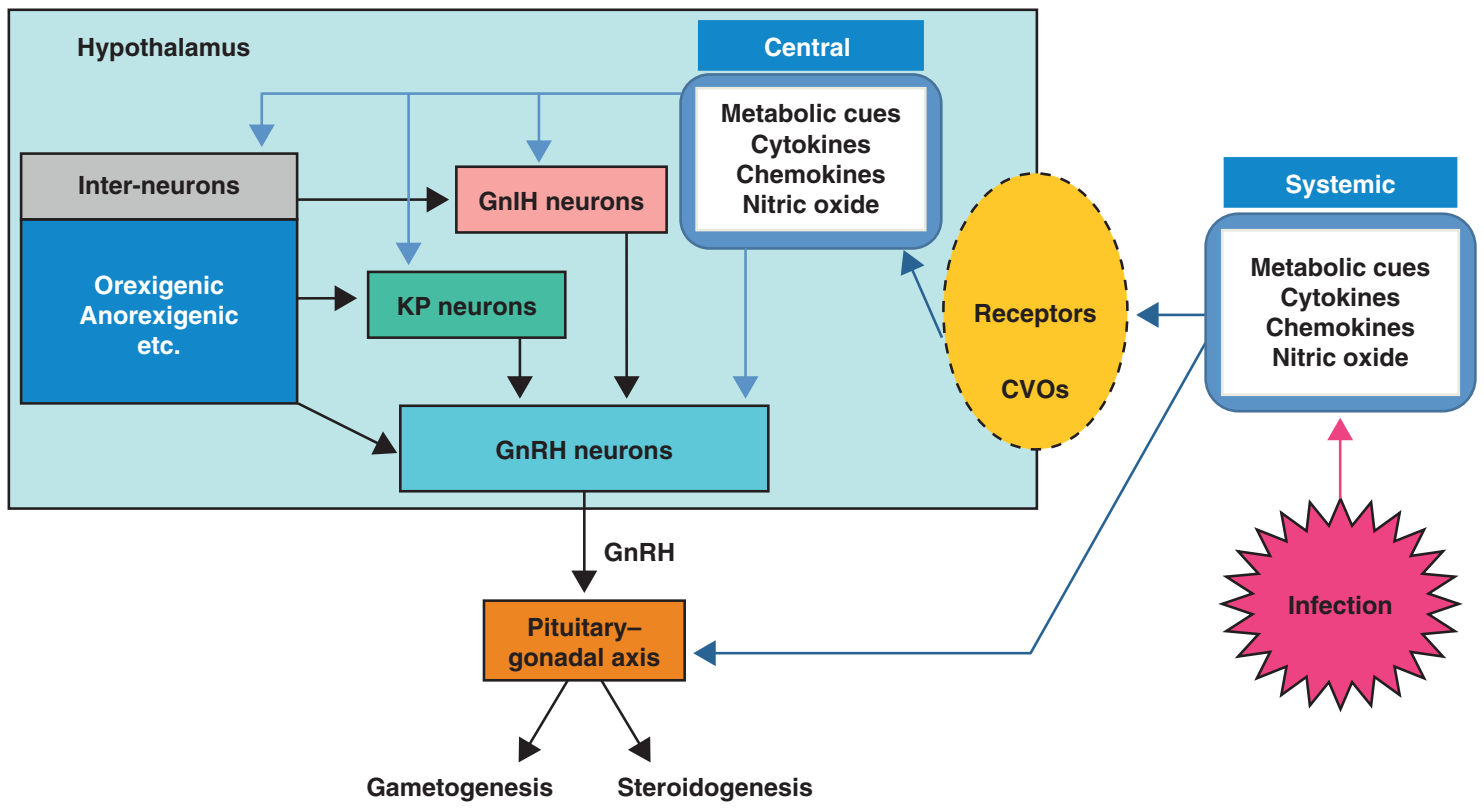

\section{Figure 4}

A schematic representation of a possible mechanism by which infection/ immune challenges may affect the neuroendocrine network regulating reproductive functions. Infection/immune challenges cause changes in metabolic cues in addition to resulting in excessive release of cytokines, chemokines, and nitric oxide (NO). These factors enter the hypothalamus either directly or bind with its receptors on the projections of hypothalamic

anti-inflammatory drug. Moreover, it was observed that exogenous KP injection greatly increased systemic levels of LH in LPS-injected animals just like placebo animals (Iwasa et al. 2008, 2014, Castellano et al. 2010b). These results suggest that KP-containing cells are highly sensitive to immune/inflammatory challenges and convey these signals to the network of GnRH-containing neurons in the hypothalamus. There is no literature on the effect of infection/immune challenges on GnIH in mammals. However, a recent study in birds has reported no effect of LPS on hypothalamic GnIH expression even though the expression of $\mathrm{GnRH}$ was significantly lowered in these birds (Lopes et al. 2012).

\section{Future perspective}

Recent findings of alterations in adiposity, body weight, glucose homeostasis, and metabolism, particularly in adult females in the absence of KP signaling, has point to the major importance of this signaling circuitry, especially in females (Tolson et al. 2014). However, further studies are needed to clarify the causes of the differences in $\mathrm{KP}$ signaling for these metabolic parameters between males and females. neurons in areas outside the blood-brain barrier such as circumventricular organs (CVO). Altered metabolic cues, cytokines, and NO can affect the activity of $\mathrm{GnRH}$ neurons directly as well as indirectly through $\mathrm{KP}$ and $\mathrm{GnIH}$ cells or via other interneurons. These signals can also act on pituitary gonadotropes to alter gonadotropin discharge. A full colour version of this figure is available at http://dx.doi.org/10.1530/JOE-14-0688.

The mechanism underlying the human post-ejaculatory refractory period is still not fully clear. Very recently, Pazhoohi \& Saied Salehi (2013) have proposed an hypothesis about the possible involvement of $\mathrm{GnIH}$ in the post-ejaculatory refractory period after orgasm. It would be worthwhile to test this hypothesis in experimental models. Many studies have described the involvement of oxytocin and prolactin in the post-ejaculatory refractory period (Ogawa et al. 1980, Krüger et al. 2003, Corona et al. 2012). The recent observations that GnIH modulates the secretion of oxytocin (Kaewwongse et al. 2011) further strengthen a possible involvement of this hormone in the post-ejaculatory refractory period. A comparison of GnIH and KP expression before, between, and after orgasm in animal models is required to ascertain the involvement of these hormones. Moreover, analysis of the metabolic cues in this setup and comparison of the expression of GnIH and KP would also be worth considering.

The metabolic significance of such a huge rise in systemic KP concentration during pregnancy (Horikoshi et al. 2003, Reynolds et al. 2009) remains largely unknown. Indeed, further research studies are needed to unveil any possible involvement of KP in pregnancy-related metabolic perturbations.

Published by Bioscientifica Lto 
Although KP neurons express LepR, and Kiss1 expression is modulated by leptin administration in conditions of energy imbalance, recent evidence has suggested an indirect action of leptin on KP neurons because leptin administration did not alter STAT3 expression in these neurons (Louis et al. 2011). Therefore, more studies are needed to determine the contributions of other leptin-activated hypothalamic signaling pathways to changes in KP neuronal activities. Moreover, Donato et al. (2011) demonstrated that specific deletion of LepR from KP cells in the hypothalamus did not affect $\mathrm{LH}$ secretion. In the same vein, re-expression of LepR in $L e p R$ null mice also did not improve infertility phenotype in animals (Cravo et al. 2013). These findings suggest that KP signaling is not crucial for linking leptin action with reproduction. Therefore, it will be interesting to know whether leptin administration would reverse metabolic deficiency-induced reproductive quiescence after the KPKiss1r signaling pathway blockade or ablation. As GnRH neurons do not express LepR, leptin acts indirectly via interneurons on these central regulators of the reproduction (Quennell et al. 2009, Donato et al. 2011, Zuure et al. 2013, Bellefontaine et al. 2014, Martin et al. 2014). Indeed, in the available literature, many hypothalamic neuronal pathways have been described to mediate leptin action on GnRH (Quennell et al. 2009, Donato et al. 2011, Zuure et al. 2013, Bellefontaine et al. 2014, Martin et al. 2014). Besides central hypothalamic actions, a number of studies suggest that leptin can also act directly on pituitary gonadotropes to modulate LH secretion (Crane et al. 2007, Akhter et al. 2014). GnIH can also act on pituitary gonadotropes to inhibit LH secretion (Ubuka et al. 2009b, 2014, McGuire \& Bentley 2010, Anjum et al. 2014), whether leptin modulates this direct action of GnIH on gonadotropes warrants further investigations.

\section{Conclusion}

Herein, we summarized compelling evidence which suggests an active involvement of KP and GnIH in the metabolic regulation of reproduction. GnIH and KP neurons are located in a strategic position in the hypothalamus, where they collect information regarding the body's current metabolic status from various peripheral and central sources (Fig. 2) (Qi et al. 2009, Castellano et al. 2010a, Sanchez-Garrido \& Tena-Sempere 2013, Wahab et al. 2013a, Batool et al. 2014, Poling et al. 2014, Sabet Sarvestani et al. 2014) and communicate them to the hypothalamic neural circuits regulating the HPG axis. $\mathrm{GnIH}$ and KP can provide this relay of metabolic information both directly and indirectly. In the former case, GnIH and KP neurons perceive metabolic information from either metabolic cues or orexigenic and anorexigenic neurons and then pass them to the GnRH neuronal network. In the latter case, GnIH and KP neurons obtain data regarding the body's metabolic status from circulating metabolic cues and neurons of feeding and satiety centers and then transfers it via interneurons to the neuronal network.

\section{Declaration of interest}

The authors declare that there is no conflict of interest that could be perceived as prejudicing the impartiality of the review reported.

\section{Funding}

F W holds a Georg Forster Fellowship of the Alexander von Humboldt Foundation. Experimental work in M S's laboratory, which is summarized in this review, is funded by Higher Education commission of Pakistan. Funding for research work in R B's laboratory is provided by the German Primate Center, which is a Leibniz Institute financed by the Federal Republic of Germany and the federal states.

Author contribution statement

$\mathrm{FW}$ drew the figures and wrote the first draft of this review article. M S and $\mathrm{R} B$ edited and added to this review article. All authors read and approved the final version of the manuscript.

\section{References}

Akhter N, CarlLee T, Syed MM, Odle AK, Cozart MA, Haney AC, Allensworth-James ML, Beneš H \& Childs GV 2014 Selective deletion of leptin receptors in gonadotropes reveals activin and GnRH-binding sites as leptin targets in support of fertility. Endocrinology $\mathbf{1 5 5}$ 4027-4042. (doi:10.1210/en.2014-1132)

Aloi JA, Bergendahl M, Iranmanesh A \& Veldhuis JD 1997 Pulsatile intravenous gonadotropin-releasing hormone administration averts fasting-induced hypogonadotropism and hypoandrogenemia in healthy, normal weight men. Journal of Clinical Endocrinology and Metabolism 82 1543-1548.

Anjum S, Krishna A \& Tsutsui K 2014 Inhibitory roles of the mammalian GnIH ortholog RFRP3 in testicular activities in adult mice. Journal of Endocrinology 223 79-91. (doi:10.1530/JOE-14-0333)

Backholer K, Smith J \& Clarke IJ 2009 Melanocortins may stimulate reproduction by activating orexin neurons in the dorsomedial hypothalamus and kisspeptin neurons in the preoptic area of the ewe. Endocrinology 150 5488-5497. (doi:10.1210/en.2009-0604)

Backholer K, Smith JT, Rao A, Pereira A, Iqbal J, Ogawa S, Li Q \& Clarke IJ 2010 Kisspeptin cells in the ewe brain respond to leptin and communicate with neuropeptide $\mathrm{Y}$ and proopiomelanocortin cells. Endocrinology 151 2233-2243. (doi:10.1210/en.2009-1190)

Batool A, Naz R, Wazir M, Azam A, Ullah R, Wahab F \& Shahab M 2014 Acute fasting-induced repression of the hypothalamic-pituitarygonadal axis is reversed by RF-9 administration in the adult male macaque. Hormone and Metabolic Research 46 927-832. (doi:10.1055/ s-0034-1387788)

Published by Bioscientifica Ltd 
Beisel WR 1995 Herman Award Lecture, 1995: infection-induced malnutrition - from cholera to cytokines. American Journal of Clinical Nutrition 62 813-819.

Bellefontaine N, Chachlaki K, Parkash J, Vanacker C, Colledge W, d' AanglemontdeTassigny X, Garthwaite J, Bouret SG \& Prevot V 2014 Leptin-dependent neuronal NO signaling in the preoptic hypothalamus facilitates reproduction. Journal of Clinical Investigation 124 2550-2559. (doi:10.1172/JCI65928)

Bentley GE, Tsutsui K \& Kriegsfeld LJ 2010 Recent studies of gonadotropininhibitory hormone (GnIH) in the mammalian hypothalamus, pituitary and gonads. Brain Research 1364 62-71. (doi:10.1016/j. brainres.2010.10.001)

Bergendahl M, Perheentupa A \& Huhtaniemi I 1991 Starvation-induced suppression of pituitary-testicular function in rats is reversed by pulsatile gonadotropin-releasing hormone substitution. Biology of Reproduction 44 413-419. (doi:10.1095/biolreprod44.3.413)

Boyle M \& Roth SL 2012 Personal Nutrition, edn 8. Cengage Learning.

Brown RE, Imran SA, Ur E \& Wilkinson M 2008 KiSS-1 mRNA in adipose tissue is regulated by sex hormones and food intake. Molecular and Cellular Endocrinology 281 64-72. (doi:10.1016/j.mce.2007.10.011)

Brown RSE, Herbison AE \& Grattan DR 2014 Prolactin regulation of kisspeptin neurones in the mouse brain and its role in the lactation-induced suppression of kisspeptin expression. Journal of Neuroendocrinology 26 898-908. (doi:10.1111/jne.12223)

Budak E, Fernández Sánchez M, Bellver J, Cerveró A, Simón C \& Pellicer A 2006 Interactions of the hormones leptin, ghrelin, adiponectin, resistin, and PYY3-36 with the reproductive system. Fertility and Sterility 85 1563-1581. (doi:10.1016/j.fertnstert.2005.09.065)

Cameron JL 1991 Metabolic cues for the onset of puberty. Hormone Research 36 97-103. (doi:10.1159/000182141)

Cameron JL 1996 Regulation of reproductive hormone secretion in primates by short-term changes in nutrition. Reviews of Reproduction $\mathbf{1}$ 117-126. (doi:10.1530/ror.0.0010117)

Cameron JL, Weltzin TE, McConaha C, Helmreich DL \& Kaye WH 1991 Slowing of pulsatile luteinizing hormone secretion in men after fortyeight hours of fasting. Journal of Clinical Endocrinology and Metabolism 73 35-41. (doi:10.1210/jcem-73-1-35)

Casanueva FF \& Dieguez C 1999 Neuroendocrine regulation and actions of leptin. Frontiers in Endocrinology 20 317-363.

Castellano JM \& Tena-Sempere M 2013 Metabolic regulation of kisspeptin. Advances in Experimental Medicine and Biology 784 363-383.

Castellano JM, Navarro VM, Fernández-Fernández R, Nogueiras R, Tovar S, Roa J, Vazquez MJ, Vigo E, Casanueva FF, Aguilar E et al. 2005 Changes in hypothalamic KiSS-1 system and restoration of pubertal activation of the reproductive axis by kisspeptin in undernutrition. Endocrinology 146 3917-3925. (doi:10.1210/en.2005-0337)

Castellano JM, Navarro VM, Fernández-Fernández R, Roa J, Vigo E, Pineda R, Dieguez C, Aguilar E, Pinilla L \& Tena-Sempere M 2006 Expression of hypothalamic KiSS-1 system and rescue of defective gonadotropic responses by kisspeptin in streptozotocin-induced diabetic male rats. Diabetes 55 2602-2610. (doi:10.2337/db05-1584)

Castellano JM, Bentsen AH, Mikkelsen JD \& Tena-Sempere M $2010 a$ Kisspeptins: bridging energy homeostasis and reproduction. Brain Research 1364 129-138. (doi:10.1016/j.brainres.2010.08.057)

Castellano JM, Bentsen AH, Romero M, Pineda R, Ruiz-Pino F, Garcia-Galiano D, Sánchez-Garrido MA, Pinilla L, Mikkelsen JD \& Tena-Sempere M 2010b Acute inflammation reduces kisspeptin immunoreactivity at the arcuate nucleus and decreases responsiveness to kisspeptin independently of its anorectic effects. American Journal of Physiology. Endocrinology and Metabolism 299 E54-E61. (doi:10.1152/ ajpendo.00081.2010)

Cejudo Roman A, Pinto FM, Dorta I, Almeida TA, Hernández M, Illanes M, Tena-Sempere M \& Candenas L 2012 Analysis of the expression of neurokinin B, kisspeptin, and their cognate receptors NK3R and KISS1R in the human female genital tract. Fertility and Sterility 97 1213-1219. (doi:10.1016/j.fertnstert.2012.02.021)
Clarke IJ 2011 Control of GnRH secretion: one step back. Frontiers in Endocrinology 32 367-375.

Clarke IJ \& Caraty A 2013 Kisspeptin and seasonality of reproduction. Advances in Experimental Medicine and Biology 784 411-430.

Clarke IJ \& Parkington HC 2014 Gonadotropin inhibitory hormone (GnIH) as a regulator of gonadotropes. Molecular and Cellular Endocrinology 385 36-44. (doi:10.1016/j.mce.2013.08.017)

Clarke IJ, Smith JT, Henry BA, Oldfield BJ, Stefanidis A, Millar RP, Sari IP, Chng K, Fabre-Nys C, Caraty A et al. 2012 Gonadotropin-inhibitory hormone is a hypothalamic peptide that provides a molecular switch between reproduction and feeding. Neuroendocrinology 95 305-316. (doi:10.1159/000332822)

Clarkson J \& Herbison AE 2006 Postnatal development of kisspeptin neurons in mouse hypothalamus; sexual dimorphism and projections to gonadotropin-releasing hormone neurons. Endocrinology 147 5817-5825. (doi:10.1210/en.2006-0787)

Cleary MP, Bergstrom HM, Dodge TL, Getzin SC, Jacobson MK \& Phillips FC 2001 Restoration of fertility in young obese (Lep(ob) Lep(ob)) male mice with low dose recombinant mouse leptin treatment. International Journal of Obesity and Related Metabolic Disorders 25 95-97. (doi:10.1038/ sj.ijo.0801525)

Clough RW, Kienast SG \& Steger RW 1998 Reproductive endocrinopathy in acute streptozotocin-induced diabetic male rats. Studies on LHRH. Endocrine 8 37-43. (doi:10.1385/ENDO:8:1:37)

Corona G, Jannini EA, Vignozzi L, Rastrelli G \& Maggi M 2012 The hormonal control of ejaculation. Nature Reviews. Urology 9 508-519. (doi:10.1038/nrurol.2012.147)

Crane C, Akhter N, Johnson BW, Iruthayanathan M, Syed F, Kudo A, Zhou YH \& Childs GV 2007 Fasting and glucose effects on pituitary leptin expression: is leptin a local signal for nutrient status? Journal of Histochemistry and Cytochemistry 55 1059-1073. (doi:10.1369/jhc. 7A7214.2007)

Cravo RM, Frazao R, Perello M, Osborne-LawrenceS, Williams KW, Zigman JM, Vianna C \& Elias CF 2013 Leptin signaling in Kiss1 neurons arises after pubertal development. PLOS ONE 8 e58698. (doi:10.1371/journal.pone. 0058698)

Crown A, Clifton DK \& Steiner RA 2007 Neuropeptide signaling in the integration of metabolism and reproduction. Neuroendocrinology $\mathbf{8 6}$ 175-182. (doi:10.1159/000109095)

D’ Anglemont de Tassigny X, Fagg LA, Dixon JPC, Day K, Leitch HG, Hendrick AG, Zahn D, Franceschini I, Caraty A \& Carlton MBL 2007 Hypogonadotropic hypogonadism in mice lacking a functional Kiss1 gene. PNAS 104 10714-10719. (doi:10.1073/pnas.0704114104)

Decourt C, Tillet Y, Caraty A, Franceschini I \& Briant C 2008 Kisspeptin immunoreactive neurons in the equine hypothalamus Interactions with GnRH neuronal system. Journal of Chemical Neuroanatomy 36 131-137. (doi:10.1016/j.jchemneu.2008.07.008)

Denis RG, Williams G \& Vernon RG 2003 Regulation of serum leptin and its role in the hyperphagia of lactation in the rat. Journal of Endocrinology 176 193-203. (doi:10.1677/joe.0.1760193)

De Roux N, Genin E, Carel J-C, Matsuda F, Chaussain J-L \& Milgrom E 2003 Hypogonadotropic hypogonadism due to loss of function of the KiSS1-derived peptide receptor GPR54. PNAS 100 10972-10976. (doi:10.1073/pnas.1834399100)

Di Giorgio NP, Catalano PN, López PV, González B, Semaan SJ, López GC, Kauffman AS, Rulli SB, Somoza GM \& Bettler B 2013 Lack of functional GABAB receptors alters Kiss1, Gnrh1 and Gad1 mRNA expression in the medial basal hypothalamus at postnatal day 4. Neuroendocrinology 98 212-223. (doi:10.1159/000355631)

Donato J, Cravo RM, Frazão R, Gautron L, Scott MM, Lachey J, Castro IA, Margatho LO, Lee S, Lee C et al. 2011 Leptin's effect on puberty in mice is relayed by the ventral premammillary nucleus and does not require signaling in Kiss1 neurons. Journal of Clinical Investigation 121 355-368. (doi:10.1172/JCI45106)

Ducret E, Anderson GM \& Herbison AE 2009 RFamide-related peptide-3, a mammalian gonadotropin-inhibitory hormone ortholog, regulates

Published by Bioscientifica Ltd 
gonadotropin-releasing hormone neuron firing in the mouse. Endocrinology 150 2799-2804. (doi:10.1210/en.2008-1623)

Dumalska I, Wu M, Morozova E, Liu R, van den Pol A \& Alreja M 2008 Excitatory effects of the puberty-initiating peptide kisspeptin and group I metabotropic glutamate receptor agonists differentiate two distinct subpopulations of gonadotropin-releasing hormone neurons. Journal of Neuroscience 28 8003-8013. (doi:10.1523/JNEUROSCI.1225-08.2008)

Escobar S, Servili A, Espigares F, Gueguen M-M, Brocal I, Felip A, Gómez A, Carrillo M, Zanuy S \& Kah O 2013 Expression of kisspeptins and kiss receptors suggests a large range of functions for kisspeptin systems in the brain of the European sea bass. PLoS ONE 8 e70177. (doi:10.1371/ journal.pone.0070177)

Forbes S, Li XF, Kinsey-Jones J \& O'Byrne K 2009 Effects of ghrelin on Kisspeptin mRNA expression in the hypothalamic medial preoptic area and pulsatile luteinising hormone secretion in the female rat. Neuroscience Letters 460 143-147. (doi:10.1016/j.neulet.2009.05.060)

Foster DL \& Olster DH 1985 Effect of restricted nutrition on puberty in the lamb: patterns of tonic luteinizing hormone ( $\mathrm{LH})$ secretion and competency of the LH surge system. Endocrinology 116 375-381. (doi:10.1210/endo-116-1-375)

Frazao R, Dungan Lemko HM, da Silva RP, Ratra DV, Lee CE, Williams KW, Zigman JM \& Elias CF 2014 Estradiol modulates Kiss1 neuronal response to ghrelin. American Journal of Physiology. Endocrinology and Metabolism 306 E606-E614. (doi:10.1152/ajpendo.00211.2013)

Fu L-Y \& van den Pol AN 2010 Kisspeptin directly excites anorexigenic proopiomelanocortin neurons but inhibits orexigenic neuropeptide $\mathrm{Y}$ cells by an indirect synaptic mechanism. Journal of Neuroscience $\mathbf{3 0}$ 10205-10219. (doi:10.1523/JNEUROSCI.2098-10.2010)

Funes S, Hedrick JA, Vassileva G, Markowitz L, Abbondanzo S, Golovko A, Yang S, Monsma FJ \& Gustafson EL 2003 The KiSS-1 receptor GPR54 is essential for the development of the murine reproductive system. Biochemical and Biophysical Research Communications 312 1357-1363. (doi:10.1016/j.bbrc.2003.11.066)

Galusca B, Jeandel L, Germain N, Alexandre D, Leprince J, Anouar Y, Estour B $\&$ Chartrel N 2012 Orexigenic neuropeptide 26RFa: new evidence for an adaptive profile of appetite regulation in anorexia nervosa. Journal of Clinical Endocrinology and Metabolism 97 2012-2018. (doi:10.1210/ jc.2011-3396)

García-Galiano D, Pineda R, Roa J, Ruiz-Pino F, Sánchez-Garrido MA Castellano JM, Aguilar E, Navarro VM, Pinilla L \& Tena-Sempere M 2012 Differential modulation of gonadotropin responses to kisspeptin by aminoacidergic, peptidergic, and nitric oxide neurotransmission. American Journal of Physiology. Endocrinology and Metabolism 303 E1252-E1263.

George JT \& Seminara SB 2012 Kisspeptin and the hypothalamic control of reproduction: lessons from the human. Endocrinology 153 5130-5136. (doi:10.1210/en.2012-1429)

George JT, Veldhuis JD, Tena-Sempere M, Millar RP \& Anderson RA 2013 Exploring the pathophysiology of hypogonadism in men with type 2 diabetes: kisspeptin-10 stimulates serum testosterone and LH secretion in men with type 2 diabetes and mild biochemical hypogonadism. Clinical Endocrinology 79 100-104. (doi:10.1111/cen.12103)

Gojska NM \& Belsham DD 2014 Glucocorticoid receptor-mediated regulation of Rfrp (GnIH) and Gpr147 (GnIH-R) synthesis in immortalized hypothalamic neurons. Molecular and Cellular Endocrinology 384 23-31. (doi:10.1016/j.mce.2013.12.015)

Goodman RL, Hileman SM, Nestor CC, Porter KL, Connors JM, Hardy SL, Millar RP, Cernea M, Coolen LM \& Lehman MN 2013 Kisspeptin, neurokinin $\mathrm{B}$, and dynorphin act in the arcuate nucleus to control activity of the GnRH pulse generator in ewes. Endocrinology 154 4259-4269. (doi:10.1210/en.2013-1331)

Gottsch ML, Cunningham MJ, Smith JT, Popa SM, Acohido BV, Crowley WF, Seminara S, Clifton DK \& Steiner RA 2004 A role for kisspeptins in the regulation of gonadotropin secretion in the mouse. Endocrinology 145 4073-4077. (doi:10.1210/en.2004-0431)

Grumbach MM 2002 The neuroendocrinology of human puberty revisited. Hormone Research 57(Suppl 2) 2-14. (doi:10.1159/000058094)
Hameed S, Jayasena CN \& Dhillo WS 2011 Kisspeptin and fertility. Journal of Endocrinology 208 97-105. (doi:10.1677/JOE-10-0265)

Han S-K, Gottsch ML, Lee KJ, Popa SM, Smith JT, Jakawich SK, Clifton DK, Steiner RA \& Herbison AE 2005 Activation of gonadotropin-releasing hormone neurons by kisspeptin as a neuroendocrine switch for the onset of puberty. Journal of Neuroscience 25 11349-11356. (doi:10.1523/ JNEUROSCI.3328-05.2005)

Hill JW, Elmquist JK \& Elias CF 2008 Hypothalamic pathways linking energy balance and reproduction. American Journal of Physiology. Endocrinology and Metabolism 294 E827-E832. (doi:10.1152/ajpendo.00670.2007)

Hinuma S, Shintani Y, Fukusumi S, Iijima N, Matsumoto Y, Hosoya M, Fujii R, Watanabe T, Kikuchi K, Terao Y et al. 2000 New neuropeptides containing carboxy-terminal RFamide and their receptor in mammals. Nature Cell Biology 2 703-708. (doi:10.1038/35036326)

Horikoshi Y, Matsumoto H, Takatsu Y, Ohtaki T, Kitada C, Usuki S \& Fujino M 2003 Dramatic elevation of plasma metastin concentrations in human pregnancy: metastin as a novel placenta-derived hormone in humans. Journal of Clinical Endocrinology and Metabolism 88 914-919. (doi:10.1210/jc.2002-021235)

Howland BE \& Zebrowski EJ 1976 Some effects of experimentally-induced diabetes on pituitary-testicular relationships in rats. Hormone and Metabolic Research 8 465-469. (doi:10.1055/s-0028-1093597)

Howland BE \& Zebrowski EJ 1980 Pituitary response to gonadotropinreleasing hormone in diabetic male rats. Experientia 36 610-611. (doi:10.1007/BF01965832)

Irfan S, Ehmcke J, Wahab F, Shahab M \& Schlatt S 2014 Intratesticular action of kisspeptin in rhesus monkey (Macaca mulatta). Andrologia 46 610-617. (doi:10.1111/and.12121)

Irwig MS, Fraley GS, Smith JT, Acohido BV, Popa SM, Cunningham MJ, Gottsch ML, Clifton DK \& Steiner RA 2004 Kisspeptin activation of gonadotropin releasing hormone neurons and regulation of KiSS-1 mRNA in the male rat. Neuroendocrinology $\mathbf{8 0} 264-272$. (doi:10.1159/000083140)

Iwasa T, Matsuzaki T, Murakami M, Shimizu F, Kuwahara A, Yasui T \& Irahara M 2008 Decreased expression of kisspeptin mediates acute immune/inflammatory stress-induced suppression of gonadotropin secretion in female rat. Journal of Endocrinological Investigation 31 656-659. (doi:10.1007/BF03345620)

Iwasa T, Matsuzaki T, Tungalagsuvd A, Munkhzaya M, Kawami T, Niki H, Kato T, Kuwahara A, Uemura H, Yasui T et al. 2014 Hypothalamic Kiss1 and RFRP gene expressions are changed by a high dose of lipopolysaccharide in female rats. Hormones and Behavior 66 309-316. (doi:10.1016/j.yhbeh.2014.06.007)

Jacobi JS, Coleman HA, Enriori PJ, Parkington HC, Li Q, Pereira A, Cowley MA \& Clarke IJ 2013 Paradoxical effect of gonadotrophin-inhibiting hormone to negatively regulate neuropeptide Y neurones in mouse arcuate nucleus. Journal of Neuroendocrinology 25 1308-1317. (doi:10.1111/jne.12114)

Jahanara M, Tamadon A, Shirazi J, Reza M, Rahmanifar F, Sabet Sarvestani F, Tanideh N, Moghadam A \& Niazi A 2014 Long term malnutrition and mRNAs expression of RFRP-3 and KiSS-1 in hypothalamus of female ovariectomized rats. Physiology and Pharmacology 17 370-378.

Johnson MA, Tsutsui K \& Fraley GS 2007 Rat RFamide-related peptide-3 stimulates GH secretion, inhibits LH secretion, and has variable effects on sex behavior in the adult male rat. Hormones and Behavior $\mathbf{5 1}$ 171-180. (doi:10.1016/j.yhbeh.2006.09.009)

Kaewwongse M, Takayanagi Y \& Onaka T 2011 Effects of RFamide-related peptide (RFRP)-1 and RFRP-3 on oxytocin release and anxiety-related behaviour in rats. Journal of Neuroendocrinology 23 20-27. (doi:10.1111/ j.1365-2826.2010.02077.x)

Kageyama H, Takenoya F, Kita T, Hori T, Guan J-L \& Shioda S 2005 Galaninlike peptide in the brain: effects on feeding, energy metabolism and reproduction. Regulatory Peptides 126 21-26. (doi:10.1016/j.regpep. 2004.08.029)

Kennedy GC \& Mitra J $1963 a$ Body weight and food intake as initiating factors for puberty in the rat. Journal of Physiology $166408-418$. (doi:10.1113/jphysiol.1963.sp007112) 
Kennedy GC \& Mitra J $1963 b$ Hypothalamic control of energy balance and the reproductive cycle in the rat. Journal of Physiology 166 395-407. (doi:10.1113/jphysiol.1963.sp007111)

Kim GL, Dhillon SS \& Belsham DD 2010 Kisspeptin directly regulates neuropeptide $\mathrm{Y}$ synthesis and secretion via the ERK1/2 and p38 mitogen-activated protein kinase signaling pathways in NPY-secreting hypothalamic neurons. Endocrinology 151 5038-5047. (doi:10.1210/ en.2010-0521)

Kinoshita M, Moriyama R, Tsukamura H \& Maeda K-I 2003 A rat model for the energetic regulation of gonadotropin secretion: role of the glucosesensing mechanism in the brain. Domestic Animal Endocrinology 25 109-120. (doi:10.1016/S0739-7240(03)00050-X)

Kinsey-Jones JS, Li XF, Knox AMI, Wilkinson ES, Zhu XL, Chaudhary AA, Milligan SR, Lightman SL \& O'Byrne KT 2009 Down-regulation of hypothalamic kisspeptin and its receptor, Kiss1r, mRNA expression is associated with stress-induced suppression of luteinising hormone secretion in the female rat. Journal of Neuroendocrinology 21 20-29. (doi:10.1111/j.1365-2826.2008.01807.x)

Kriegsfeld LJ 2013 Circadian regulation of kisspeptin in female reproductive functioning. Advances in Experimental Medicine and Biology 784 385-410.

Kriegsfeld LJ, Mei DF, Bentley GE, Ubuka T, Mason AO, Inoue K, Ukena K, Tsutsui K \& Silver R 2006 Identification and characterization of a gonadotropin-inhibitory system in the brains of mammals. PNAS 103 2410-2415. (doi:10.1073/pnas.0511003103)

Krüger THC, Haake P, Haverkamp J, Krämer M, Exton MS, Saller B, Leygraf N, Hartmann U \& Schedlowski M 2003 Effects of acute prolactin manipulation on sexual drive and function in males. Journal of Endocrinology 179 357-365.

Lapatto R, Pallais JC, Zhang D, Chan Y-M, Mahan A, Cerrato F, Lee WW, Hoffman GE \& Seminara SB 2007 Kiss 1 - / - mice exhibit more variable hypogonadism than Gpr54-/ - mice. Endocrinology 148 4927-4936. (doi:10.1210/en.2007-0078)

Lee LR, Paul SJ \& Smith MS 1989 Dose response effects of pulsatile GnRH administration on restoration of pituitary GnRH receptors and pulsatile LH secretion during lactation. Neuroendocrinology 49 664-668. (doi:10.1159/000125185)

Lee JH, Miele ME, Hicks DJ, Phillips KK, Trent JM, Weissman BE \& Welch DR 1996 KiSS-1, a novel human malignant melanoma metastasissuppressor gene. Journal of the National Cancer Institute 88 1731-1737. (doi:10.1093/jnci/88.23.1731)

Lee DK, Nguyen T, O’Neill GP, Cheng R, Liu Y, Howard AD, Coulombe N, Tan CP, Tang-Nguyen AT, George SR et al. 1999 Discovery of a receptor related to the galanin receptors. FEBS letters 446 103-107. (doi:10.1016/ S0014-5793(99)00009-5)

Lents CA, Heidorn NL, Barb CR \& Ford JJ 2008 Central and peripheral administration of kisspeptin activates gonadotropin but not somatotropin secretion in prepubertal gilts. Reproduction 135 879-887. (doi:10.1530/REP-07-0502)

Leupen SM, Besecke LM \& Levine JE 1997 Neuropeptide Y Y1-receptor stimulation is required for physiological amplification of preovulatory luteinizing hormone surges. Endocrinology 138 2735-2739.

Li X, Su J, Lei Z, Zhao Y, Jin M, Fang R, Zheng L \& Jiao Y 2012 Gonadotropin-inhibitory hormone $(\mathrm{GnIH})$ and its receptor in the female pig: cDNA cloning, expression in tissues and expression pattern in the reproductive axis during the estrous cycle. Peptides 36 176-185. (doi:10.1016/j.peptides.2012.05.008)

Linkie DM \& Niswender GD 1972 Serum levels of prolactin, luteinizing hormone, and follicle stimulating hormone during pregnancy in the rat. Endocrinology 90 632-637. (doi:10.1210/endo-90-3-632)

Liu X \& Herbison AE 2008 Small-conductance calcium-activated potassium channels control excitability and firing dynamics in gonadotropinreleasing hormone (GnRH) neurons. Endocrinology 149 3598-3604. (doi:10.1210/en.2007-1631)

Liu X, Lee K \& Herbison AE 2008 Kisspeptin excites gonadotropin-releasing hormone neurons through a phospholipase C/calcium-dependent pathway regulating multiple ion channels. Endocrinology 149 4605-4614. (doi:10.1210/en.2008-0321)

Liu X, Brown RSE, Herbison AE \& Grattan DR 2014 Lactational anovulation in mice results from a selective loss of kisspeptin input to GnRH neurons. Endocrinology 155 193-203. (doi:10.1210/en. 2013-1621)

Lopes PC, Wingfield JC \& Bentley GE 2012 Lipopolysaccharide injection induces rapid decrease of hypothalamic GnRH mRNA and peptide, but does not affect GnIH in zebra finches. Hormones and Behavior 62 173-179. (doi:10.1016/j.yhbeh.2012.06.007)

Louis GW, Greenwald-Yarnell M, Phillips R, Coolen LM, Lehman MN \& Myers MG 2011 Molecular mapping of the neural pathways linking leptin to the neuroendocrine reproductive axis. Endocrinology 152 2302-2310. (doi:10.1210/en.2011-0096)

Luque RM, Kineman RD \& Tena-Sempere M 2007 Regulation of hypothalamic expression of KiSS-1 and GPR54 genes by metabolic factors: analyses using mouse models and a cell line. Endocrinology 148 4601-4611. (doi:10.1210/en.2007-0500)

Marsteller FA \& Lynch CB 1983 Reproductive consequences of food restriction at low temperature in lines of mice divergently selected for thermoregulatory nesting. Behavior Genetics 13 397-410. (doi:10.1007/ BF01065777)

Martin C, Navarro VM, Simavli S, Vong L, Carroll RS, Lowell BB \& Kaiser UB 2014 Leptin-responsive GABAergic neurons regulate fertility through pathways that result in reduced kisspeptinergic tone. Journal of Neuroscience 34 6047-6056. (doi:10.1523/JNEUROSCI.3003-13.2014)

Matsui H, Takatsu Y, Kumano S, Matsumoto H \& Ohtaki T 2004 Peripheral administration of metastin induces marked gonadotropin release and ovulation in the rat. Biochemical and Biophysical Research Communications 320 383-388. (doi:10.1016/j.bbrc.2004.05.185)

McConn B, Wang G, Yi J, Gilbert ER, Osugi T, Ubuka T, Tsutsui K, Chowdhury VS, Furuse M \& Cline MA 2014 Gonadotropin-inhibitory hormone-stimulation of food intake is mediated by hypothalamic effects in chicks. Neuropeptides 48 327-334. (doi:10.1016/j.npep.2014. 09.001)

McGuire NL \& Bentley GE 2010 A functional neuropeptide system in vertebrate gonads: gonadotropin-inhibitory hormone and its receptor in testes of field-caught house sparrow (Passer domesticus). General and Comparative Endocrinology 166 565-572. (doi:10.1016/ j.ygcen.2010.01.010)

Messager S, Chatzidaki EE, Ma D, Hendrick AG, Zahn D, Dixon J, Thresher RR, Malinge I, Lomet D, Carlton MBL et al. 2005 Kisspeptin directly stimulates gonadotropin-releasing hormone release via $\mathrm{G}$ proteincoupled receptor 54. PNAS 102 1761-1766. (doi:10.1073/pnas. 0409330102)

Morin LP 1975 Effects of various feeding regimens and photoperiod or pinealectomy on ovulation in the hamster. Biology of Reproduction $\mathbf{1 3}$ 99-103. (doi:10.1095/biolreprod13.1.99)

Morishige WK, Pepe GJ \& Rothchild I 1973 Serum luteinizing hormone, prolactin and progesterone levels during pregnancy in the rat. Endocrinology 92 1527-1530. (doi:10.1210/endo-92-5-1527)

Moschos S, Chan JL \& Mantzoros CS 2002 Leptin and reproduction: a review. Fertility and Sterility 77 433-444. (doi:10.1016/S00150282(01)03010-2)

Mounzih K, Lu R \& Chehab FF 1997 Leptin treatment rescues the sterility of genetically obese ob/ob males. Endocrinology 138 1190-1193.

Muir AI, Chamberlain L, Elshourbagy NA, Michalovich D, Moore DJ, Calamari A, Szekeres PG, Sarau HM, Chambers JK, Murdock P et al. 2001 AXOR12, a novel human G protein-coupled receptor, activated by the peptide KiSS-1. Journal of Biological Chemistry 276 28969-28975. (doi:10.1074/jbc.M102743200)

Navarro VM, Castellano JM, Fernández-Fernández R, Tovar S, Roa J, Mayen A, Nogueiras R, Vazquez MJ, Barreiro ML, Magni P et al. 2005a Characterization of the potent luteinizing hormone-releasing activity of KiSS-1 peptide, the natural ligand of GPR54. Endocrinology 146 156-163. (doi:10.1210/en.2004-0836) 
Navarro VM, Castellano JM, Fernández-Fernández R, Tovar S, Roa J, Mayen A, Barreiro ML, Casanueva FF, Aguilar E, Dieguez C et al. 2005b Effects of KiSS-1 peptide, the natural ligand of GPR54, on follicle-stimulating hormone secretion in the rat. Endocrinology 146 1689-1697. (doi:10.1210/en.2004-1353)

Nestor CC, Kelly MJ \& Rønnekleiv OK 2014 Cross-talk between reproduction and energy homeostasis: central impact of estrogens, leptin and kisspeptin signaling. Hormone Molecular Biology and Clinical Investigation 17 109-128. (doi:10.1515/hmbci-2013-0050)

Ogawa S \& Parhar IS 2014 Structural and functional divergence of gonadotropin-inhibitory hormone from jawless fish to mammals. Frontiers in Endocrinology 5 177. (doi:10.3389/fendo.2014.00177)

Ogawa S, Kudo S, Kitsunai Y \& Fukuchi S 1980 Increase in oxytocin secretion at ejaculation in male. Clinical Endocrinology 13 95-97. (doi:10.1111/j.1365-2265.1980.tb01027.x)

Ohga H, Adachi H, Matsumori K, Kodama R, Nyuji M, Selvaraj S, Kato K, Yamamoto S, Yamaguchi A \& Matsuyama M 2015 mRNA levels of kisspeptins, kisspeptin receptors, and GnRH1 in the brain of chub mackerel during puberty. Comparative Biochemistry and Physiology. Part A, Molecular \& Integrative Physiology 179 104-112. (doi:10.1016/j. cbpa.2014.09.012)

Ohtaki T, Shintani Y, Honda S, Matsumoto H, Hori A, Kanehashi K, Terao Y, Kumano S, Takatsu Y, Masuda Y et al. 2001 Metastasis suppressor gene KiSS-1 encodes peptide ligand of a G-protein-coupled receptor. Nature 411 613-617. (doi:10.1038/35079135)

Okamura H, Tsukamura H, Ohkura S, Uenoyama Y, Wakabayashi Y \& Maeda K 2013 Kisspeptin and GnRH pulse generation. Advances in Experimental Medicine and Biology 784 297-323.

Osugi T, Ubuka T \& Tsutsui K 2014 Review: evolution of GnIH and related peptides structure and function in the chordates. Frontiers in Neuroscience 8 255. (doi:10.3389/fnins.2014.00255)

Parfitt DB, Church KR \& Cameron JL 1991 Restoration of pulsatile luteinizing hormone secretion after fasting in rhesus monkeys (Macaca mulatta): dependence on size of the refeed meal. Endocrinology 129 749-756. (doi:10.1210/endo-129-2-749)

Parhar IS, Ogawa S \& Sakuma Y 2004 Laser-captured single digoxigeninlabeled neurons of gonadotropin-releasing hormone types reveal a novel G protein-coupled receptor (Gpr54) during maturation in cichlid fish. Endocrinology 145 3613-3618. (doi:10.1210/en.2004-0395)

Pazhoohi F \& Saied Salehi M 2013 Effect of gonadotropin inhibitory hormone $(\mathrm{GnIH})$ secretion on post-ejaculatory refractory period: a hypothesis. Hypothesis 11. (doi:10.5779/hypothesis.v11i1.286)

Perrigo G \& Bronson FH 1983 Foraging effort, food intake, fat deposition and puberty in female mice. Biology of Reproduction 29 455-463. (doi:10.1095/biolreprod29.2.455)

Pielecka-Fortuna J, Chu Z \& Moenter SM 2008 Kisspeptin acts directly and indirectly to increase gonadotropin-releasing hormone neuron activity and its effects are modulated by estradiol. Endocrinology 149 1979-1986. (doi:10.1210/en.2007-1365)

Pineda R, Garcia-Galiano D, Sanchez-Garrido MA, Romero M, Ruiz-Pino F, Aguilar E, Dijcks FA, Blomenröhr M, Pinilla L, van Noort PI et al. 2010 a Characterization of the inhibitory roles of RFRP3, the mammalian ortholog of $\mathrm{GnIH}$, in the control of gonadotropin secretion in the rat: in vivo and in vitro studies. American Journal of Physiology. Endocrinology and Metabolism 299 E39-E46. (doi:10.1152/ajpendo.00108.2010)

Pineda R, Garcia-Galiano D, Sanchez-Garrido MA, Romero M, Ruiz-Pino F, Aguilar E, Dijcks FA, Blomenröhr M, Pinilla L, van Noort PI et al. $2010 b$ Characterization of the potent gonadotropin-releasing activity of RF9, a selective antagonist of RF-amide-related peptides and neuropeptide FF receptors: physiological and pharmacological implications. Endocrinology 151 1902-1913. (doi:10.1210/en.2009-1259)

Pinilla L, Aguilar E, Dieguez C, Millar RP \& Tena-Sempere M 2012 Kisspeptins and reproduction: physiological roles and regulatory mechanisms. Physiological Reviews 92 1235-1316. (doi:10.1152/ physrev.00037.2010)
Poling MC, Shieh MP, Munaganuru N, Luo E \& Kauffman AS 2014 Examination of the Influence of leptin and acute metabolic challenge on RFRP-3 neurons of mice in development and adulthood. Neuroendocrinology. (doi:10.1159/000369276)

Pralong FP \& Gaillard RC 2001 Neuroendocrine effects of leptin. Pituitary 4 25-32. (doi:10.1023/A:1012930609563)

Pusztai P, Sarman B, Ruzicska E, Toke J, Racz K, Somogyi A \& Tulassay Z 2008 Ghrelin: a new peptide regulating the neurohormonal system, energy homeostasis and glucose metabolism. Diabetes/Metabolism Research and Reviews 24 343-352. (doi:10.1002/dmrr.830)

Qi Y, Oldfield BJ \& Clarke IJ 2009 Projections of RFamide-related peptide-3 neurones in the ovine hypothalamus, with special reference to regions regulating energy balance and reproduction. Journal of Neuroendocrinology 21 690-697. (doi:10.1111/j.1365-2826.2009.01886.x)

Qiu X, Dowling AR, Marino JS, Faulkner LD, Bryant B, Brüning JC, Elias CF \& Hill JW 2013 Delayed puberty but normal fertility in mice with selective deletion of insulin receptors from Kiss1 cells. Endocrinology 154 1337-1348. (doi:10.1210/en.2012-2056)

Quaynor S, Hu L, Leung PK, Feng H, Mores N, Krsmanovic LZ \& Catt KJ 2007 Expression of a functional g protein-coupled receptor 54-kisspeptin autoregulatory system in hypothalamic gonadotropinreleasing hormone neurons. Molecular Endocrinology 21 3062-3070. (doi:10.1210/me.2007-0207)

Quennell JH, Mulligan AC, Tups A, Liu X, Phipps SJ, Kemp CJ, Herbison AE, Grattan DR \& Anderson GM 2009 Leptin indirectly regulates gonadotropin-releasing hormone neuronal function. Endocrinology 150 2805-2812. (doi:10.1210/en.2008-1693)

Quennell JH, Howell CS, Roa J, Augustine RA, Grattan DR \& Anderson GM 2011 Leptin deficiency and diet-induced obesity reduce hypothalamic kisspeptin expression in mice. Endocrinology 152 1541-1550. (doi:10.1210/en.2010-1100)

Ratra DV \& Elias CF 2014 Chemical identity of hypothalamic neurons engaged by leptin in reproductive control. Journal of Chemical Neuroanatomy 61-62 233-238.

Reynolds RM, Logie JJ, Roseweir AK, McKnight AJ \& Millar RP 2009 A role for kisspeptins in pregnancy: facts and speculations. Reproduction 138 1-7. (doi:10.1530/REP-09-0026)

Rizwan MZ, Poling MC, Corr M, Cornes PA, Augustine RA, Quennell JH, Kauffman AS \& Anderson GM 2012 RFamide-related peptide-3 receptor gene expression in GnRH and kisspeptin neurons and GnRHdependent mechanism of action. Endocrinology 153 3770-3779. (doi:10.1210/en.2012-1133)

Rizwan MZ, Harbid AA, Inglis MA, Quennell JH \& Anderson GM 2014 Evidence that hypothalamic RFamide related peptide-3 neurones are not leptin-responsive in mice and rats. Journal of Neuroendocrinology $\mathbf{2 6}$ 247-257. (doi:10.1111/jne.12140)

Roa J \& Tena-Sempere M 2014 Connecting metabolism and reproduction: roles of central energy sensors and key molecular mediators. Molecular and Cellular Endocrinology 397 4-14. (doi:10.1016/j.mce.2014.09.027)

Roa J, Vigo E, Castellano JM, Navarro VM, Fernández-Fernández R, Casanueva FF, Dieguez C, Aguilar E, Pinilla L \& Tena-Sempere M 2006 Hypothalamic expression of KiSS-1 system and gonadotropin-releasing effects of kisspeptin in different reproductive states of the female rat. Endocrinology 147 2864-2878. (doi:10.1210/en.2005-1463)

Russell JA, Douglas AJ \& Ingram CD 2001 Brain preparations for maternity adaptive changes in behavioral and neuroendocrine systems during pregnancy and lactation. An overview. Progress in Brain Research 133 1-38.

Sabet Sarvestani F, Tamadon A, Koohi-Hosseinabadi O, Mohammadi Nezhad S, Rahmanifar F, Jafarzadeh Shirazi MR, Tanideh N, Moghadam A \& Niazi A 2014 Expression of RFamide-related peptide-3 (RFRP-3) mRNA in dorsomedial hypothalamic nucleus and KiSS-1 mRNA in arcuate nucleus of rat during pregnancy. International Journal of Fertility \& Sterility $8333-340$.

Sanchez-Garrido MA \& Tena-Sempere M 2013 Metabolic control of puberty: roles of leptin and kisspeptins. Hormones and Behavior 64 187-194. (doi:10.1016/j.yhbeh.2013.01.014) 
Sari IP, Rao A, Smith JT, Tilbrook AJ \& Clarke IJ 2009 Effect of RF-amiderelated peptide- 3 on luteinizing hormone and follicle-stimulating hormone synthesis and secretion in ovine pituitary gonadotropes. Endocrinology 150 5549-5556. (doi:10.1210/en.2009-0775)

Schenck PE, Slob AK, Uilenbroek JT \& van der Werff ten Bosch JJ 1980 Effect of neonatal undernutrition on serum follicle-stimulating hormone levels and ovarian development in the female rat. British Journal of Nutrition 44 179-182. (doi:10.1079/BJN19800025)

Seminara SB \& Kaiser UB 2005 New gatekeepers of reproduction: GPR54 and its cognate ligand, KiSS-1. Endocrinology 146 1686-1688. (doi:10.1210/en.2005-0070)

Seminara SB, Messager S, Chatzidaki EE, Thresher RR, Acierno JS, Shagoury JK, Bo-Abbas Y, Kuohung W, Schwinof KM, Hendrick AG et al. 2003 The GPR54 gene as a regulator of puberty. New England Journal of Medicine 349 1614-1627. (doi:10.1056/NEJMoa035322)

Sexton WJ \& Jarow JP 1997 Effect of diabetes mellitus upon male reproductive function. Urology 49 508-513. (doi:10.1016/S00904295(96)00573-0)

Shahab M, Zaman W, Bashir K \& Arslan M 1997 Fasting-induced suppression of hypothalamic-pituitary-gonadal axis in the adult rhesus monkey: evidence for involvement of excitatory amino acid neurotransmitters. Life Sciences 61 1293-1300. (doi:10.1016/S00243205(97)00674-7)

Shahab M, Mastronardi C, Seminara SB, Crowley WF, Ojeda SR \& Plant TM 2005 Increased hypothalamic GPR54 signaling: a potential mechanism for initiation of puberty in primates. PNAS 102 2129-2134. (doi:10.1073/pnas.0409822102)

Smith MS 1978 A comparison of pituitary responsiveness to luteinizing hormone-releasing hormone during lactation and the estrous cycle of the rat. Endocrinology 102 114-120. (doi:10.1210/endo-102-1-114)

Smith JT 2009 Sex steroid control of hypothalamic Kiss1 expression in sheep and rodents: comparative aspects. Peptides 30 94-102. (doi:10.1016/j.peptides.2008.08.013)

Smith JT 2012 The role of kisspeptin and gonadotropin inhibitory hormone in the seasonal regulation of reproduction in sheep. Domestic Animal Endocrinology 43 75-84. (doi:10.1016/j.domaniend.2011.11.003)

Smith JT 2013 Sex steroid regulation of kisspeptin circuits. Advances in Experimental Medicine and Biology 784 275-295.

Smith JT \& Clarke IJ 2010 Gonadotropin inhibitory hormone function in mammals. Trends in Endocrinology and Metabolism 21 255-260. (doi:10.1016/j.tem.2009.11.010)

Smith MS \& Grove KL 2002 Integration of the regulation of reproductive function and energy balance: lactation as a model. Frontiers in Endocrinology 23 225-256.

Smith JT, Acohido BV, Clifton DK \& Steiner RA 2006 KiSS-1 neurones are direct targets for leptin in the ob/ob mouse. Journal of Neuroendocrinology 18 298-303. (doi:10.1111/j.1365-2826.2006.01417.x)

Smith JT, Clay CM, Caraty A \& Clarke IJ 2007 KiSS-1 messenger ribonucleic acid expression in the hypothalamus of the ewe is regulated by sex steroids and season. Endocrinology 148 1150-1157. (doi:10.1210/en.2006-1435)

Smith JT, Coolen LM, Kriegsfeld LJ, Sari IP, Jaafarzadehshirazi MR, Maltby M, Bateman K, Goodman RL, Tilbrook AJ, Ubuka T et al. 2008 Variation in kisspeptin and RFamide-related peptide (RFRP) expression and terminal connections to gonadotropin-releasing hormone neurons in the brain: a novel medium for seasonal breeding in the sheep. Endocrinology 149 5770-5782. (doi:10.1210/en.2008-0581)

Smith MS, True C \& Grove KL 2010 $a$ The neuroendocrine basis of lactationinduced suppression of GnRH: role of kisspeptin and leptin. Brain Research 1364 139-152. (doi:10.1016/j.brainres.2010.08.038)

Smith JT, Shahab M, Pereira A, Pau K-YF \& Clarke IJ 2010b Hypothalamic expression of KISS1 and gonadotropin inhibitory hormone genes during the menstrual cycle of a non-human primate. Biology of Reproduction 83 568-577. (doi:10.1095/biolreprod.110.085407)

Spindler-Vomachka M \& Johnson DC 1985 Altered hypothalamicpituitary function in the adult female rat with streptozotocin-induced diabetes. Diabetologia 28 38-44. (doi:10.1007/BF00276998)
Stengel A, Wang L, Goebel-Stengel M \& Taché Y 2011 Centrally injected kisspeptin reduces food intake by increasing meal intervals in mice. Neuroreport 22 253-257. (doi:10.1097/WNR.0b013e32834558df)

Suzuki Y, Nakahara K, Maruyama K, Okame R, Ensho T, Inoue Y \& Murakami N 2014 Changes in mRNA expression of arcuate nucleus appetite-regulating peptides during lactation in rats. Journal of Molecular Endocrinology 52 97-109. (doi:10.1530/JME-13-0015)

Tachibana T, Sato M, Takahashi H, Ukena K, Tsutsui K \& Furuse M 2005 Gonadotropin-inhibiting hormone stimulates feeding behavior in chicks. Brain Research 1050 94-100. (doi:10.1016/j.brainres.2005.05.035)

Teles MG, Bianco SDC, Brito VN, Trarbach EB, Kuohung W, Xu S, Seminara SB, Mendonca BB, Kaiser UB \& Latronico AC 2008 A GPR54-activating mutation in a patient with central precocious puberty. New England Journal of Medicine 358 709-715. (doi:10.1056/NEJMoa073443)

Tena-Sempere M 2013 Interaction between energy homeostasis and reproduction: central effects of leptin and ghrelin on the reproductive axis. Hormone and Metabolic Research 45 919-927. (doi:10.1055/s-0033-1355399)

Tena-Sempere M, Felip A, Gómez A, Zanuy S \& Carrillo M 2012 Comparative insights of the kisspeptin/kisspeptin receptor system: lessons from non-mammalian vertebrates. General and Comparative Endocrinology 175 234-243. (doi:10.1016/j.ygcen.2011.11.015)

Terasawa E \& Fernandez DL 2001 Neurobiological mechanisms of the onset of puberty in primates. Endocrine Reviews 22 111-151.

Terasawa E, Kurian JR, Keen KL, Shiel NA, Colman RJ \& Capuano SV 2012 Body weight impact on puberty: effects of high-calorie diet on puberty onset in female rhesus monkeys. Endocrinology 153 1696-1705. (doi:10.1210/en.2011-1970)

Terasawa E, Guerriero KA \& Plant TM 2013 Kisspeptin and puberty in mammals. Advances in Experimental Medicine and Biology 784 253-273.

Thompson EL, Patterson M, Murphy KG, Smith KL, Dhillo WS, Todd JF, Ghatei MA \& Bloom SR 2004 Central and peripheral administration of kisspeptin-10 stimulates the hypothalamic-pituitary-gonadal axis. Journal of Neuroendocrinology 16 850-858. (doi:10.1111/j.1365-2826. 2004.01240.x)

Tolson KP, Garcia C, Yen S, Simonds S, Stefanidis A, Lawrence A, Smith JT \& Kauffman AS 2014 Impaired kisspeptin signaling decreases metabolism and promotes glucose intolerance and obesity. Journal of Clinical Investigation 124 3075-3079. (doi:10.1172/JCI71075)

True C, Verma S, Grove KL \& Smith MS 2013 Cocaine- and amphetamineregulated transcript is a potent stimulator of $\mathrm{GnRH}$ and kisspeptin cells and may contribute to negative energy balance-induced reproductive inhibition in females. Endocrinology 154 2821-2832. (doi:10.1210/en. 2013-1156)

Tsutsui K, Saigoh E, Ukena K, Teranishi H, Fujisawa Y, Kikuchi M, Ishii S \& Sharp PJ 2000 A novel avian hypothalamic peptide inhibiting gonadotropin release. Biochemical and Biophysical Research Communications 275 661-667. (doi:10.1006/bbrc.2000.3350)

Tsutsui K, Bentley GE, Bedecarrats G, Osugi T, Ubuka T \& Kriegsfeld LJ 2010 Gonadotropin-inhibitory hormone (GnIH) and its control of central and peripheral reproductive function. Frontiers in Endocrinology $\mathbf{3 1}$ 284-295.

Ubuka T, Kim S, Huang Y, Reid J, Jiang J, Osugi T, Chowdhury VS, Tsutsui K \& Bentley GE 2008 Gonadotropin-inhibitory hormone neurons interact directly with gonadotropin-releasing hormone-I and -II neurons in European starling brain. Endocrinology 149 268-278. (doi:10.1210/en.2007-0983)

Ubuka T, Lai H, Kitani M, Suzuuchi A, Pham V, Cadigan PA, Wang A, Chowdhury VS, Tsutsui K \& Bentley GE 2009a Gonadotropininhibitory hormone identification, cDNA cloning, and distribution in rhesus macaque brain. Journal of Comparative Neurology 517 841-855. (doi:10.1002/cne.22191)

Ubuka T, Morgan K, Pawson AJ, Osugi T, Chowdhury VS, Minakata H, Tsutsui K, Millar RP \& Bentley GE $2009 b$ Identification of human GnIH homologs, RFRP-1 and RFRP-3, and the cognate receptor, GPR147 in 
the human hypothalamic-pituitary axis. PLOS ONE 4 e8400. (doi:10.1371/journal.pone.0008400)

Ubuka T, Inoue K, Fukuda Y, Mizuno T, Ukena K, Kriegsfeld LJ \& Tsutsui K 2012 Identification, expression, and physiological functions of Siberian hamster gonadotropin-inhibitory hormone. Endocrinology 153 373-385. (doi:10.1210/en.2011-1110)

Ubuka T, Son YL, Bentley GE, Millar RP \& Tsutsui K 2013 Gonadotropininhibitory hormone $(\mathrm{GnIH}), \mathrm{GnIH}$ receptor and cell signaling. General and Comparative Endocrinology 190 10-17. (doi:10.1016/j.ygcen. 2013.02.030)

Ubuka T, Son YL, Tobari Y, Narihiro M, Bentley GE, Kriegsfeld LJ \& Tsutsui K 2014 Central and direct regulation of testicular activity by gonadotropin-inhibitory hormone and its receptor. Frontiers in Endocrinology 5 8. (doi:10.3389/fendo.2014.00008)

Verma S, Kirigiti MA, Millar RP, Grove KL \& Smith MS 2014 Endogenous kisspeptin tone is a critical excitatory component of spontaneous GnRH activity and the GnRH response to NPY and CART. Neuroendocrinology 99 190-203. (doi:10.1159/000365419)

Wada N, Hirako S, Takenoya F, Kageyama H, Okabe M \& Shioda S 2014 Leptin and its receptors. Journal of Chemical Neuroanatomy 61-62 191-199.

Wade GN \& Jones JE 2004 Neuroendocrinology of nutritional infertility. American Journal of Physiology. Regulatory, Integrative and Comparative Physiology 287 R1277-R1296. (doi:10.1152/ajpregu. 00475.2004)

Wahab F, Aziz F, Irfan S, Zaman W-U \& Shahab M 2008 Short-term fasting attenuates the response of the HPG axis to kisspeptin challenge in the adult male rhesus monkey (Macaca mulatta). Life Sciences 83 633-637. (doi:10.1016/j.lfs.2008.09.001)

Wahab F, Bano R, Jabeen S, Irfan S \& Shahab M 2010 Effect of peripheral kisspeptin administration on adiponectin, leptin, and resistin secretion under fed and fasting conditions in the adult male rhesus monkey (Macaca mulatta). Hormone and Metabolic Research 42 570-574. (doi:10.1055/s-0030-1252016)

Wahab F, Ullah F, Chan Y-M, Seminara SB \& Shahab M $2011 a$ Decrease in hypothalamic Kiss1 and Kiss1r expression: a potential mechanism for fasting-induced suppression of the HPG axis in the adult male rhesus monkey (Macaca mulatta). Hormone and Metabolic Research 43 81-85. (doi:10.1055/s-0030-1269852)

Wahab F, Quinton R \& Seminara SB 2011b The kisspeptin signaling pathway and its role in human isolated GnRH deficiency. Molecular and Cellular Endocrinology 346 29-36. (doi:10.1016/j.mce.2011.05.043)

Wahab F, Riaz T \& Shahab M 2011c Study on the effect of peripheral kisspeptin administration on basal and glucose-induced insulin secretion under fed and fasting conditions in the adult male rhesus monkey (Macaca mulatta). Hormone and Metabolic Research 43 37-42. (doi:10.1055/s-0030-1268458)

Wahab F, Zaman W-U \& Shahab M 2012 Differential response of the primate HPG axis to $N$-methyl-D, L-aspartate, but not to Kisspeptin challenge under euglycemic and hypoglycemic conditions. Hormone and Metabolic Research 44 451-457. (doi:10.1055/s0032-1306309)

Wahab F, Atika B \& Shahab M $2013 a$ Kisspeptin as a link between metabolism and reproduction: evidences from rodent and primate studies. Metabolism: Clinical and Experimental 62 898-910. (doi:10.1016/j.metabol.2013.01.015)

Wahab F, Atika B, Oliveira-Pelegrin GR \& Rocha MJA 2013b Recent advances in the understanding of sepsis-induced alterations in the neuroendocrine system. Endocrine, Metabolic \& Immune Disorders Drug Targets 13 335-347. (doi:10.2174/1871530313666131211120723)

Wahab F, Atika B, Huma T \& Shahab M 2014 Primate HPT axis response to the peripheral kisspeptin challenge under different time periods of food restriction in monkeys. Hormone and Metabolic Research 46 187-192. (doi:10.1055/s-0033-1363263)

Wu M, Dumalska I, Morozova E, van den Pol A \& Alreja M 2009 Melaninconcentrating hormone directly inhibits GnRH neurons and blocks kisspeptin activation, linking energy balance to reproduction. PNAS 106 17217-17222. (doi:10.1073/pnas.0908200106)

Wynne K, Stanley S, McGowan B \& Bloom S 2005 Appetite control. Journal of Endocrinology 184 291-318. (doi:10.1677/joe.1.05866)

Yamada S, Uenoyama Y, Kinoshita M, Iwata K, Takase K, Matsui H, Adachi S, Inoue K, Maeda K-I \& Tsukamura H 2007 Inhibition of metastin (kisspeptin-54)-GPR54 signaling in the arcuate nucleus-median eminence region during lactation in rats. Endocrinology 148 2226-2232. (doi:10.1210/en.2006-1529)

Yoshida H, Habata Y, Hosoya M, Kawamata Y, Kitada C \& Hinuma S 2003 Molecular properties of endogenous RFamide-related peptide-3 and its interaction with receptors. Biochimica et Biophysica Acta 1593 151-157. (doi:10.1016/S0167-4889(02)00389-0)

Yousefabad A, Leili S, Tamadon A, Rahmanifar F, Shirazi J, Reza M, Sabet Sarvestani F, Tanideh N, Moghadam A, Asghar A et al. 2013 Lactation effect on the mRNAs expression of RFRP-3 and KiSS-1 in dorsomedial and arcuate nuclei of the rat hypothalamus. Physiology and Pharmacology 17 277-285.

Zuure WA, Roberts AL, Quennell JH \& Anderson GM 2013 Leptin signaling in GABA neurons, but not glutamate neurons, is required for reproductive function. Journal of Neuroscience 33 17874-17883. (doi:10.1523/JNEUROSCI.2278-13.2013)

Accepted 23 March 2015 (c) 2015 The authors Printed in Great Britain
Published by Bioscientifica Ltd 